\title{
Verlangen en verleiden
}

\author{
Citation for published version (APA):
}

Foppen, J. W. (2004). Verlangen en verleiden. Maastricht University. https://doi.org/10.26481/spe.20040415wf

Document status and date:

Published: 15/04/2004

DOI:

10.26481/spe.20040415wf

Document Version:

Publisher's PDF, also known as Version of record

\section{Please check the document version of this publication:}

- A submitted manuscript is the version of the article upon submission and before peer-review. There can be important differences between the submitted version and the official published version of record.

People interested in the research are advised to contact the author for the final version of the publication, or visit the DOI to the publisher's website.

- The final author version and the galley proof are versions of the publication after peer review.

- The final published version features the final layout of the paper including the volume, issue and page numbers.

Link to publication

\footnotetext{
General rights rights.

- You may freely distribute the URL identifying the publication in the public portal. please follow below link for the End User Agreement:

www.umlib.nl/taverne-license

Take down policy

If you believe that this document breaches copyright please contact us at:

repository@maastrichtuniversity.nl

providing details and we will investigate your claim.
}

Copyright and moral rights for the publications made accessible in the public portal are retained by the authors and/or other copyright owners and it is a condition of accessing publications that users recognise and abide by the legal requirements associated with these

- Users may download and print one copy of any publication from the public portal for the purpose of private study or research.

- You may not further distribute the material or use it for any profit-making activity or commercial gain

If the publication is distributed under the terms of Article $25 \mathrm{fa}$ of the Dutch Copyright Act, indicated by the "Taverne" license above, 


\section{Verlangen en Verleiden}

"April is the cruellest month, breeding

Lilacs out of the dead land, mixing

Memory and desire..." 


\section{Colofon}

Bossontwerp en reafisatie: Ungraphic Universtest Madstricht.

Omslag-ifhustratie: De rondeval wan Adam door Michelangelo

Fresco- $1508-1512$, sixtinge kapel Woticaan

$158 N 90-5681+198-3$

NUR 808

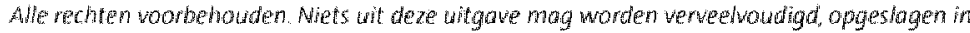

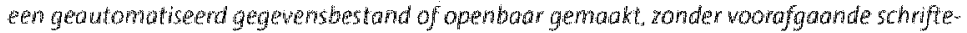
Hhe toestemming wan de auteur of uitgever 


\section{Verlangen en Verleiden}

\section{Oratie}

gehouden bij gelegenheid van de aanvaarding van het hoogleraarschap Strategisch Leiderschap aan de Faculteit der Economische Wetenschappen \& Bedriffikunde

\section{Prof. Dr. J. Wil Foppen}





\section{Verlangen en Verleiden}

Oratie bij de gelegenheid van het publiek aanvarden wan mijn eerdere benoeming tot hoogleraar Strategisch Leiderschap.

\section{Vooraf}

Mijn oratie, indertijd bij de aanvarding vain het hoogleraarschap in de Bedrijfskunde aan de Erasmus Universiteit Rotterdam, over 'Weten wat wat Waard is: de Ontwikkeling van Managers als Kennismanagement' begon heel bewust met een citaat van T.5. Eliot, dat alles samenvatte:

"... the end of all our exploring

Will be to arrive where we started

And know the place for the first time."

Toen wist ik nog niet dat dat ook op mijzelf sloeg en dat ik, wat dat betreft, na zoveel jaren zou terugkeren, naap war ik ben geboren, naar school ben gegaan en madien helass afscheid nam van mijn ouders en oudste broer.

Het is voor mij een bijzonder voorrecht hier te mogen staan om in uw aller aanwezigheid met het uitspreken van deze rede, het mij al eerder toegekende hoogleraarschap in Strategisch Leiderschap aan de Universiteit Maastrichț publiekelijk te aanwarden.

Ik doe dat wederom met een citaat van de onbuigzame en weerbar stige T.5. Eliot:

"April is the cruellest month, breeding

Lilacs out of the dead land, mixing

Memory and desire..."

In het navolgende hoop ik u toe te lichtem dat het verlangen of "desi$r^{\prime \prime}$, waarvan in de titel van deze oratie, respectievelijk in het citat sprake is, wis en waarachtig de kern vormt van wat men hier aan deze gereputeerde Faculteit der Economische Wetenschappen en Bedrijfskunde van mij verwacht.

Deze oratie zal gaan over aspecten en voorwaarden wan strategische leiderschapsontwikkeling oftewel management educatie, wat daarvan 
de uitdagingen zijn en dat dat niet alleen relateert aan leiderschap. maar er ook om vraagt.

Velen willen graag als een leider gezien en erkend worden. ik zal hen proberen te verleiden daartoe eerst en vooral aan zichzelf te gaan werken. Doen ze dat goed, dan hoeft die erkenning niet meer zo nodig. Dan is het verlangen leider te ziln vrijwel verleden en blijkt leiderschap meer nabij.

Management educatie en leiderschap hebben veel met elkaar gemeen. Management educatie is het verlangen naar waar men graag wil komen, maar waarwan men dan nog niet weet dat die wens en haar vervulling gaandeweg veranderen, zonder dat dat afdoet aan het te willen.

Het interessante aan mensen is niet dat ze iets niet weten, maar dat ze juist zoveel weten dat niet zo hoeft te zijn. Precies daar zit de paradoxale kneep van wat management educatie is, ook bij ons als aambieders ervan. Aan de ene kant willen wil het management effectiever maken, maar aan de andere kant hoe dat nu precies moet, kunnen weper definitie. niet goed omschrijven. "The paradox is that it is only by concern of broader goals, only by taking our eye of the ball, that education will prove to be useful. What seems to be required is some, sleight of hand, some deception whereby we appear to give the client what they want, while we work to our own conception of what they need." (Thomals \& Anthony, 1996, 32)

Dat wraagt in zoveel woorden om een kunstgreep, een vorm vam misleiding waarbij het lijkt alsof de klant krijgt wat hij wil, terwijl gebeurt wat vanuit managenent educatie wordt gemeend dat nodig is. Maar dat is geenszins vriblibend, want als dat leidt tot een educationele agenda los van de managementpraktik dan leidt dat nergens toe (Foppen, 1998).

De essentie van het proces waarom het hier gaat is treffend, metaforisch verwoord in éen van de fabels van La Fontaine: "The children fpresumably) were too lazy to earm a living by working in the fields, as their fother wanted them to. So he told them instead that there was a treasure buried in the ground. Eager to get rich in a hury, they overturned the sol in an unsuccessful search for the treasure, and in doing so made is 50 fertile that they indeed got rich "(Elster, 1983.54). 
Als we straks in het tweede deel van deze oratie in het diepe duiken van wat er allemaal bij management educatie komt kijken, zo zullen we het daar aanstonds hebben over kennis als ware het verboden fruit, $2 a$ onmiddellik daaropwolgend worden aangegeven welke voor de Faculteit der Economisch Wetenschappen en Bedriffskunde (FoEWB) de ambitie is met de leerstoel Strategisch Leiderschap.

Maar eerst schets ik waar we op dit moment zijn met de nog geen twee jaar geleden opgerichte business school waaraan ik voor de FdEWB leiding mag geven.

Na dat aangegeven te hebben informeer ik w over de kaat van onderwerpen die verder nog in het eerste deel aan bod zullen komen. Het zal een kaleidoscoop van observaties, indrukken en woorkeuren zijn over lelderschap, relevante voorwaarden ertoe en aspecten ervan. Het gat aldaar dus wel degelijk over management educatie. Verlangen en verlelden komen daarbij telkens wisselend om de hoek kijken.

\section{Interlude}

Een intrigerend voorbeeld van leiderschap en sexuele verleiding is de verhouding tussen Socrates en de jonge, mooie politicus Alcibiades. Alcibiades deed er alles aan om de oude Socrates in zijn bed te krijgen. Toen dat eenmaal lukte, weigerde Socrates echter toe te geven en de schone jongeling ook maar aan te raken.

Ondanks fysiek door hem te zijn afgewezen blift Socrates voor Alcibiades voortdurend betoverend. Niet in het minst en juist omdat hil tegenover de egoistische, lichamelijke hartstocht van de jonge politicus. zichzelf volledig in de hand heeft, en oprecht en onomkoopbaar zijn eigen weg gaat. Socrates laat zien dat leiderschap niet om sex en fantasie gaat maar om balans en zelfmeesterschap. Een geest, die in vorm is. weet dat je jezelf en je omgeving in balans moet houden. Eigenbelang en macht zijh niet in iemands voordeel, ook al blijkt men de sterkste (Kessels, Boers \& Mostert, 2003. 174). 


\section{De Graduate School of International Management}

De Universiteit Mastricht als jongste onder de Nederlandse universiteiten heeft met de start van de Faculteit der Economische Wetenschappen en Bedrijfskunde een zware verplichting op zich genomen, niet in het minst vanwege de onderliggende en eigenzinnige benadering van het probleemgeorienteerde leerconcept. Dat concept had en heeft zich eerder al elders en aan de medische faculteit bewezen en heeft de Universiteit Maastricht allesbehalve windeieren gelegd.

De Faculteit der Economische Wetenschappen en Bedrijfskunde is erin geslaagd zich in korte tijd een wooraanstaande plaats te verwerven op de terreinen die haar eerste kerntaken zijn: onderzoek en onderwijs. Er zinn vele in het oog en in de prijzen springende collega-onderzoekers en onderzoeksinsitituten aan de faculteit verbonden. De terugkerende hoge notering van het Maastrichtse economische en management onderwijs op plaats één (1), is net zo uitzonderlijk.

Een maand nadat de faculteit in april 2002 de prestigieuze AACSB International accreditatie had verworven, mocht ik, met steun in de vorm van een beperkte voorfinanciering van het college van Bestuur, een begin maken met het opzetten van de nieuwe Business 5chool aan de faculteit. Door het afketsen van de pogingen om met de Maastricht School of Management die ambitie te realiseren werd alsnog geopteerd voor een "Alleingang". De "Graduate School of International Management" was daarmee geboren en draagt sindsdien substantieel bij aan de derde academische hoofdtaak van de faculteit: maatschappelijke relevantie.

Het meest intrigerende bij de opzet en ontwikkeling wan de nieuwe business school is dat het in essentie gaat om de toepasssing van het probleem georienteerde leerconcept op de faculteit zelve. Meer nog, het gat om de strategische leiderschapsontwikkeling van de faculteit in de praktijk, een veelomvattend eigen "action learning" project. Dat maakt de start ervan des te uitdagender en haar ontwikkeling des te vitaler.

De opgave waarvoor we met de nieuwe business school staan is eerst en wooral de werankering wan de faculteit en haar specifieke deskundigheid en netwerk in de samenleving c.q. in de economie van de eigen reglo, en omgekeerd de representatie van de omringende econo- 
mische en organizationele context in het onderzoek en onderwijs en dus in de expertise ontwikkeling van de faculteit yoor beide partijen. faculteit en omgeving, is woortgaande, verbredende en verdiepende professionalisering een noodzakelijke voorwaarde om zich blijuend te onderscheiden.

Een en ander betekent concreet de ontwikkeling en het aanbod van maatschappelijk erkende en hooggewaarde "postgraduate" diploma pro. gramma's voor professionals en voor 'general managers' respectievelijk voor mensen met ambitie in die richting. Aanstonds moet hierbij worden opgemerkt dat met name op het professionele traject wan financiën. financiëel beheer en accountancy al enkele jaren door collegae succesvolle programma's worden aangeboden. Dat geldt ook voor belangstellenden uit 'emerging economies" woor de professionalisering rond sociale zekerheidssystemen. De integratie van deze trajecten binnen de business schoollevert voor iedereen veel meerwaarde op.

In diezelfde context van 'postgraduate' diploma programma's is een begin beproefd met het ontwikkelen van sectorspecifieke MBA's, zoals voor de 'Life Sciences', 'Hotel \& Tourism' Management en voor de Gezondheidszorg.

De invoering van de zagenoemde Bachelor - Master structuur in het hoger onderwijs van de Europese Unie biedt unieke kansen - zij het voorlopig onder hoge onzekerheid over de doorstroomeffecten binnen dat nieuwe stelsel - omeen eigen aansprekend, intermational én nationaal profiel en dito programma portefeuille op te bouwen. De complementariteit van de niet-ervaringsgebonden diploma's met de wel ervaringsgebaseerde leertrajecten verrijkt beiden en optimaliseert carriè em recruteringsmogelijkheden.

Passen de diploma programma's binnen de door byerheden erkende competenties, minstens zo belangrijk zijn de bednjfsgerichte opleidingen en ontwikkelingsprogramma's die door de business school, veelal in samenspraak met bedrijwen, worden opgezet en vermarkt. Inmiddel's is darmee een zeer beloftevolle aanzet gemaakt. Daaronder vallen ook de contacten en samenwerking met bedrijwenorganisaties zoals bijv. Limburgse Werkgevers vereniging, andere belangenverenigingen, Kamers van Koophandel en mat ontwikkelingsinstituties als LIOF en AGII.

Verwacht mag worden dat de faculteit en de bedrijwen en organisa. 
ties uit haar private en publieke omgeving op den duur voor elkaar te prefereren, synergetische leerpartners blijken te zijn. Uiteraard wordt met de orngeving een zich gaandeweg concentrisch uitdijende en gren. zenoverschijjdende regio bedoeld.

In de directe omgeving is het zaak om naast bedrijuen ook de individuele professionals en managers te ondersteunen en uit te dagen zich samen met de business school verder te bekwamen en persoonlijk te ontwilkelen. Een begin is gemaakt met zagenoemde open programma's. cursussen en workshops, die qua inhoud veelal zijn geijkt op die van soortgelike cursussen in de diploma trajecten.

De Graduate 5 chool of International Mangement is daarnaast recent een tweetal activiteiten - en competentie centra gestart.

Het eerste is het Centrum voor Ondernemerschap, dat beoogt binnen en buiten de universiteit in de omringende Euregio ondernemerschap te stimuleren, te instrumenteren en verder te ontwikkelen. Het Centrum doet dat door middel van trainingen, cursussen, coaching en advies. Het Centrum werkt samen met ondernemers, managers, onderzoekers en andere professionals, die allen bereid zijn hun ervaringen aan el kaar uit te wisselen en hun deskundigheid met elkaar te delen.

Het tweede, onlangs gestarte centrum is het zogenoemde Center for Business Leadership, waarin eveneens praktijk. onderzoek, reflectie en toepassing van met name strategisch en transformationeel leiderschap wordt samengebracht. Op dit moment vinden gesprekken plaats met leidinggevenden van meerdere (middel)grote bedrijven over praktische leiderschapsconcepten, die hen helpen hun economische en maatschappelijke doeleinden te realiseren.

Strategische allianties en samenwerking met bedrijven en andere universiteiten over de grens ligt woor hand. Daarmee is een eerste begin gemalakt rond het MBA in Life Sciences met de Universite de Liège en met het EU-gefinancierde MABUSE programma vanuit de RWTH Aachen met nog vijf andere internationale partners.

Ilk beloofde een overzicht te geven van de verschillende thema's, die in deze oratie aan bod komen. Het spreekt voor zich dat er grote samenhang tussen bestaat. Nochtans, voor wie dat wil, kunnen ze ook afzonderlijk en los van elkaar gelezen worden. 
Koledoscoop

Vooral

Deell

2. De Graduate School of international Management

3 Verlangen naar wat onbereikbaar is

4. veriedend schrinen over leiderschap

5. Management er organisatie als Iterain genre

6. Leiderschap wie (ver)leidt wie?

pleders zijn zingevers, ze maken er war war

8 Een vrouw als leide, vergeet alles

9 Verlangen naar wijsheid (verleidt tot ambivalentie

10. De verleiding van rotionaliteit en functionaliteit

Deel II

11 Verboden kennis verboden frin

12. Stralegisch Leiderschap is geen verboden fruit

3. Is postgraducte nanagement onderwis cantrekkelljk?

14. Wot kun je bjj monagement educalie verwadten?

${ }_{5}$ En de bedriven dan met hun corporate unversities?

16. Reflexiviter op de praktjk? Hel kont goed

17 Hebzucht meer les ders willen steeds neer en meer I 


\section{Verlangen naar wat onbereikbaar is}

Als mensen pikken we alleen die signalen op, waartoe we geprogrammeerd zijm. Ons bewustzijn wordt verder beperkt door het feit dat we alleen die dingen herkennen, waarvan of waarvoor we al een soort van mentale kaart hebben.

Einstein zelf legde in 1926 uit dat het nonsens was te menen dat men een theorie kon funderen op alleen mar waarneembare feiten. In werkelikheid gebeurt: volgens hem juist het omgekeerde. Het is de theorie die bepalt wat we kunnen warnemen. Wat we zien is een kaart van de wereld en niet de wereld zelf.

Het volgend woorbeeld laat goed zien hoe grondig die kaart onze percepties stuurt. Toen in een beroemd experiment de 'Me'en' in Ethiopië voor het eerst foto's te zien kregen van imensen en dieren, waren ze niet in staat die twee-dimensionale beelden te 'lezen'. Ze voelden well aan het papier, roken eraan; vouwden het op, luisterden naar het knisperen erwan en kauwden er zelfs op om "t te proeven. Hoe anders is dat in onze eigen, moderne wereld, waar we makkelijk het gefotografeerde beeld gelijkschakelen met het gefotografeerde object of persoon, ofschoon die twee in feite slechts in zeer abstracte zin op elkaar lijken (Zander \& Zander, 2000,11 )

Toen al weer heel wat jaren terug een man in de trein naar Barcelona plots Pablo Picasso bij hem in de coupé herkende, vroeg hij die. hevig geinteresseerd, warom hij mensen mooit schilderde, zoals ze echt zijn. Picasso vroeg hem wat hij daarmee bedoelde. Kijk, zei de man, en hij haalde uit zijn binnenzak een foto van zijn vrouw: kijk zoals mijn vrouw hier.

Waarop Picasso reageende, maar is die niet erg klein en plat? (Pagels, $1988,163)$

"Pour être aimable, je n'ai qu'à ne pas vouloir ne pas le paraitre", was de worstelling van Stendhal, in zijn woortdurend pogen 'natuurlijk" te zijn. Hij was zeker dat herr dat zou lukken zodra hij geleerd zou hebben te laten zien daarim niet te zujn geinteresseerd (fister, 1983,45).

Waar het hier in essentie om gat is, dat men van binnen uit, vanuit een interne staat, niet een gewilde externe toestand of staat kan creëren, evenmin als dat het mogelijk is duisternis te scheppen met een zaklamp. 
Hegel omschrifft als zün diepste inzicht dat 'verlangen en de zelfbevestiging die resulteert uit haar bevrediging, beide worden geconditioneerd door het subject van verlangen. Zelfbevestiging komt ervoor in de plaats. Om die wisseling echter mogelijk te maken, moet het andere of de ander er eerst zijn.

Het zich niet van iets bewust zijn kan men niet doen ontstaan door een daarop gerichte bewuste handeling. Dat ontberen is in wezen een nevenprodukt.

Er zijn echter ook gendeg positief te definieren toestanden, die ons eveneens ontsnappen als we ons hoofd ernaar willen zetten of onze handen ernaar uitstrekken.

Zo kan ik mij kennis wensen, maar geen wijsheid; naar bed willen. maar niet het slapen; eten, maar niet honger; scrupules, maar geen deugd; snoeverij, maar niet moed; lust, maar niet liefde, felicitaties, maar niet bewondering; godsdiemst, maar niet geloof; lezen, mar niet te begripen (Farber, 1976, 7).

Lust is in dezen een pikant en moeilijk voorbeeid, omdat niets zo funest is voor sexueel werlangen dan het verlangen het te ervaren.

Natuurlijk kan elk van ons aan zichzelf sleutelen, zich zelf in dezen managen door te kiezen voor de een of andere indirecte manier of techniek. Slapen valt dan wel niet te commanderen, ma areen pil kan elk pakken, dat wil wel eens helpen.

Aristoteles zei het al eerder als men een deugdzaam mens wil worden, is het best te beginnen zich zo te gedragen alsof men 't al ware. Voor de goede luisteraar zit precies daar de Gordiaanse knoop van het waarden-en normendebat in dit land. Die hak je dus door, zonder zoals nu gebeurt je eerst te gaan afvragen walar de knoop zal blifven, alsof je hem anders kunt ontwarren.

Het praktisch probleem bij al deze wensen en verlangens is het best te typeren als het hangmat-probleem. Als je jezelf zacthtjes in slaap will schommelen, om op het moment als de slaap komt zo te ontspannen, dat je vergeet te schommelen, weer wakker wordt en opnieuw noet beginnen. 
stek een nevenprodukt? Men kan wel zeggen of vragen: "hou van me". maar dat kan een mens niet dáarom. Men kan wel iets doen, wat wordt gevraagd, wit liefde, maar liefde zelf creeer je niet op werzoek of op bevel. Daarom is het verlangen dat de een de ander moet liefhebben, omdat de ander erom vraagt, niet realistisch.

Nochtans vonden de wrede keizers van Rome dat indertijd wel Er waren er toen, waarvan men hield en weer anderen die eisten dat van ze gehouden moest worden. In een wan Seneca's tragedies snauwt een tiran op de vraag of hij niet bang is dat de publieke opinie zich tegen hem keert, dat keizers mensen kunnen dwingen van hen te houden. Echte macht blikt uit het feit dat je lofredes kunt afdwingen, ais een keizer zich alleen nog maar als goed mens kan gedragen, dan heeft ie zijn recht op de kroon verspeelt (Elster, 63).

"Etonne-moi" Maar kan men dan iemand - juist omdat zij of hij dat verwacht - nog wel verrassen?

Toen ik laatst met mijn dochter in Dordrecht was, kwam ze binnen en vertelde me, omdat het die dag l april was, dat ze me woor de gek zou gaan houden.

Maar er gebeurde niks. En toen ik haar naar bed bracht wroeg ik haar ernaar. ze zei, wilde jij de hele tijd dat ik je voor de gek zou houden? Ja, natuurlijk. Maar ik deed "t niet? Neen. Maar je verwachtte het wel? Ja. oh, nou, ik hield je voor de gek!

Waar gaat het in dezen allemaal om? In feite wil ik nu en vaker walschuwen tegen het geloof in instrumentele rationaliteit. Er zijn geen direche, opgelegde, geinstrumenteerde beste oplossingen, die men kan krijgen als men erom vraagt of verwerid door er hard voor te werken of studeren. Het helpt natuurlijk wel zeer om ergens heel veel vanaf te weten. maar dat is op zich nog geen voorspelbare of betroumbare garantie. Die kennis, dat vele weten, mag dan wel net als macht erg belangrijk zijn, maar om echt iets voor jezelf te kumnen betekenen, moet het ook weer niet al te serleus genomen worden.

ten latste woobeeld:

Een Zen master was voor zijn hut enkele monniken aan het onderwijzen, toen hij plots naar binnen ging, de deur sloot en de hut in brand stak. Hij riep: tenzij een van jullie het juiste woord noemt, kom ik niet naar buiten. ledereen buiten probeerde en zocht verwoed om het juiste woord te vinden. Niks lukte. Bij het naderen wan een laatkomer riep een van hen: "Kom snel, de meester heeft zich opgesloten en komt er pas uit, 
als een van ons de juiste woorden weet " "Oh, mijn god!" schreeuwde de latkomer En op dat moment kwam de meester naar buiten.

Ook hier geldt weer dat de ontworpen antwoorden niet deugden. Wat de meester wilde was iets spontaans. En de laatkomer wou helemaal niet het juiste zeggen, hij was geschokt. Had een wan de anderen "oh, mijn god!" geroepen met het doel de meester eruit te krijgen, dan zou de meester dat waarschijnlijk doorien hebben en niet naar buiten zijn gekomen (Smullyan, 1980, 95). 


\section{Verleidend schrijven over leiderschap}

Ofschoon over leiderschap zo veel geschreven wordt dat de bossen eronder lijden en iemand die dat ooit will lezen nooit meer tijd heeft om zelf ooit nog iets te leiden, blijft het - en waarschijnlijk precies daaromeen uiterst vag en moelijk te grijpen fenomeen.

"Alles is verleiding en niets dan verleiding. Ze wilden ons doen geloven dat alles productie was. Het leidmotief van de wereldtransformatie, het samenspel van produktieve krachten zorgt ervoor dat alles goed komt. Verleiding is maar immoreel, friwool, oppervlakkig ...... Maar wat als alles nu eens, anders dan wat het lijkt -stiekem als het ware- zou werken wolgens (het principe wan) verleiding?" (Baudrillard,1988, 162)

Door al dat gepraat over verleiding, komen we niet meer aan leiderschap toe. Twee feministen Calas en 5 mircich (1997) keken naar de rhetorische en culturele condities onder de organisatorische leiderschapsliteratuur als ware het een verleidingss.pel. Het naast elkaar plaatsen van leiderschap en verleiding werd de kern wan hun analyse.

Wat betekent leiderschap hier en nu? In lijn met anderen, die al eerder keken naar de rol van sexualiteit in het organisationele leven, menen zij dat de my the van leiderschap en de romantische klank eromheen de meest vitale sexualiteit schept in de organisatie literatuur. Meer in het bijzonder gaat het Calás en Smircich om verleidingseffecten waarover eerder ook al andere wetenschappers schreven, zij het dat nu de culturele grenzen van kennis wat meer worden afgetast.

In plaats van verlangen te onderdrukken - immoreel en illegaal gedrag overwint men immers door het heldhaftig ontkennen van instincten- werkt leiderschap. juist ondat het vorm geeft aan verlangen. De sporen ervan blijven echter verborgen onder het motto van het zoeken naar de wartheid.

Als een vorm van verleiding, lijkt er op zich weinig diepgaands aan leiderschap. Het is eerder een opperwlakkig spel. Dat was des te meer reden voor beide leiderschapstheoretici om opgewekt de diepten van de bestaande literatuur te exploreren en gaten op te vullen. Ze wilden minstens een deel wan de thetoriek blootleggen, warmee het verleidingsspel, in al zijn beperkingen is omgeven. 
Uiteindelijk selecteerden ze een viertal klassieke teksten uit de management en organisatie literatuur. Die vier teksten werden onderworpen aan drie verschillende post-structuralistische methoden: een historische analyse naar macht, een tekst-analytische uiteenlegging met loppositioneel) onderzoek naar betekenissen, en een analyse van leeseffecten.

Van deze vier noem ik er hier twee, ondat ik aan die beide ook de ver. leidelijkheid van de leiderschapsanalyse, waar het over gaat, zal illustreren. Dat zijn Barnard's The functions of the Executive (1938) and Mintzberg's The Nature of Managerial Work (1973/1980). Alle vier teksten en daarvan in het bijzonder de netgenoemde twee, zijn buitengewoon invloedrijk gebleken, niet alleen voor managers in de praktijk, maar ook onder collega wetenschappers.

De deconstructieve aanpak van Calás en Smircich richtte zich met name op de dubbelzinnigheid en meervoudige betekenissen in betogen en discours, die birnen bepaalde kennisgemeenschappen middels standaard interpretaties meestal worden begrensd, waarmee dan overigens tegelijkertijd de ambiguiteit (en niet precisie) worden onderstreept. Gevolg is dat de sexualiteit en verleidelijkineid binnen het discours van leiderschap naar buiten kan treden. Leiderschap is dan dus verleiding niet door wat het zegt, maar door wat het niet zegt, respectievelijk omdat nog niet bepaald is wat gezegd kan worden.

Hoe kan het dat verleiding leiderschap is en leiderschap verleiding is? In onze typische en gangbare manier van denken over organisaties is leiderschap iets goeds, iets wat nodig is. "wat we hier nodig hebben is leiderschap" wordt vaak gezegd als de dingen niet goed gaan. Zelden (nooit?) hoor je iemand roepen om wat meer verleiding. Hoe zit dat? Waarom is leiderschap goed en verleiding slecht? Calás en Smircich illustreren een en ander aan de hand vam etymalogisch onderzoek op basis van de Oxford English Dictionary (1989):

Lead to guide on a way, esp by going in advance, to direct on a course or in a drection, to serve as a channel for to have charge, 10 go at the head of to be first in or among; to have a marght over to beg $n$ to play with (trumps), to a im in front of a moving object (a duck), $t o$ direct la blowl at an opponent in boxing. 
GUlDE inplies intimate knowledge of the way and of all of its difficul. ties and dangers, LEAD implies a going ahead to show the way and often to keep those that follow under control and in order; STEER implies an ability to keep to a chosen course and stresses the capacity of manoeuvering correctly PIL or s uggests guldance over a dangerous, Intricate or complicated course. ENCINEER implies gudance by one who finds vays to avoid or overcome difficulties in achieving an end or carrying out alan

SEDUCE [L seducere to LEAD away, fr se apart t ducere to lead], to per suade to disobedience or disloyalty to lead astray, to entice into unchastly attract

\section{SYn SCE LURE; ENTICE, INVEICLE, DECOV TEMPT, SEDUCE}

LURE Implies a drawing to danger, evil, or difficu ty through attracting and decelwing ENTICE suggests drawing by artful or adroit means INVEIGLE inplies entiling by cajoling or flatterng, DECOY implies a luning into entrapment by artiflce, TEMPT Implies the presenting of an attraction 50 strong that it overcomes the restraints of conscience or better judgment, SEDUCE mplles a leading astray by persuasion of false promses.

SEDUCER One who tempts or persuades (another) to desert his allegi ance or service. Now rare or obsolete.

SEDUCTOR Dbsolete A male seducer [obsolete means no evdence of standard use since 711

SEDUCTRESS fr L. LO LEAD a Way a female seducer

Wat met name opvalt is dat verleiding leiderschap insluit: verleiden betekent lemand naar 't werkeerde pad leiden; misleiden. Verleiding heeft een slechte reputatie. Verleiding is leiderschap op de verkeerde weg.

Let er tegelijk op dat leiderschap verleiding impliceert: Leiden is aantrekken (aantrekkelijk maken) en stimuleren, overwinnen.

Dus, werleiden is (naar "t) verkeerd(e) leiden, terwijl leiden (naar "t) goed (e) verleiden is. Waarom noemen we een leider dan niet een verleider? 
Volgens het Oxford Engelse woordenboek is het mannelije werler der" (seducer/seductor) al eeuwen obsoleet. Wel bestaat nog steeds de: vrouwelijke verleidster (seductress: to lead away: a female seducer).

lemand die verleidt, verlokt of prikkelt biedt iets zo aantrekkeliks dat het de beteugeling overwint. lemand die verleidt is dus fin onze Angelsaksiche cultuur) een verleidster, verleiders bestaan niet langer. Daarom kunnen velen een leider zijn. maar alleen een wroww kan verleidster zijn. Zijn verleiders ook nog nodig als 'leider zijn' al volstaat? (Calás \& Smircich, 573).

\section{Ilustratie 1:}

Aan de hand van Barnard"s "What is leadership" illustreren Calas en Smircich door iteratie wan contexten en het gebruik van meervoudge betekenissen een andere, onderliggende en plausibele tekst voor wat door Barnard wordt bedoeld met leiderschap:

Leadership is the absolutely necessay creation of desire, a longing whing, craving, the creation of sexual attracton that promises to be satisfled throigh foithful ot tachment. There are no substitutes for gain. ing the willing contribution of efforts Leader shipdesie is the lff force of organizalions without it arganization/ he species dies

How does a leader create desire? Hirst the leader must acheve a slate of conviction an act of self seducton, where his feeling of separation from the group are totally overcome and he truly belleves that he and the group are one. He must truly assume the appearance of virue and not feign belief:

This is an executive's hardest ordeal for it means mhibithg. controlling, or nowifying his own inconsistent mpulses and intensifing those, which are consistent The fusion in the leaders mind g himself and the group lures sways, infuences mentaly or emotionaly, and caplures (seduces?) the personnel of the arganization but only if the leader s a true belever for organization's personnel con tell when you te foking it:

This creation the production of him self fused with personnel, is the red creativity of leadership. No mitations will be occepted The seduction that is leadershp depends on truth Thus in order lo create and sustain organization barnards leader seduces? 
Er valt uiteraand meer te zeggen over de deconstructieve analyse van het werk van Barnard. Niet in het minst als daarbij de ontwikkeling van het interpretatieve denken van freud wordt betrokken. Was het immers niet Freud, die uiteindelijk de werleiding, die zo dominant is in zijn werk en dus in zijn praktijk, van lieverlee maar reduceerde tot overwegend projectieve fantasie van het kind? Maatschappelik was de dreiging vam het accepteren van perverse vaders, laat staan van perverse priesters, onbespreekbaar en dus ondenkbaar. Wittgenstein's "Wovon mann nicht sprechen kann, dauber muss man schweigen" krijgt zadoende een onverwachte, extralading.

Wat kon Barnard dus anders doen. Een executive" kon toendertijd gewoonweg niet een verleider zijn, dat zou zijn positle onmiddellijk ondermijnen. De leider knijgt bij Barnard dus alsnog meer het beeld van een 'vader/priester", met het mandaat om een kudde van zondaars/verleiders an te zetten tot biecht en absolutie. Verlangen tot (ver)leiden verwoord hil graag als 'leiderschap'!

\section{Mustratie 2:}

Henry Mintzberg heeft ziln naam gevestigd in de jaren zeventig met een indrukwekkende analyse van de feitelijke aard van het dagelijkse werk van een manager. Ferst legde hij dat neer in een artikel voop Harvard Business Review (1973), daana heeft le zijn bevindingen nader uitgewerkt in het boek. The nature of managerial work (1979).

De feitelijkheid van zijn analyse: tien rollen voor managers en de extensieve beschrijuing van hun alledaagse werk leidt middels de iteratieve methode van Calás en Smircich tot een recht-toe-recht-aan beschrijving van de manager als 'verleider', aan wie het narcisme van diezelfde jaren zeventig niet vreemd is.

\section{The manager as Seducer}

The organization looks at the projection of an erection for its guldance and motrvation The leader intoduces and insinuates by pouring that which glwes new life He wil never give insufficient attention to that to which he claims

He will develop sexual affals and will be preaccupied with the body ond its camal needs the will bestow his favours and gift to those placed into his possestion 
He will constanty stimulate, excite, arouse and penetrate. He will do so because he is potent in every position. Thus he will newer restran the function of the bodily organs from those who are ardent with earnest whoses

Wh this slender instrument he vill examine every covity even if he has to be intrusive, whisting or forcing in without permission, weicome or Thers?

He will unite and form hio a whole, developing that which exists in pos sibility Like a bridegroom, husband and maste, he will produce preg. nancles when using his abilty to copulate as a male.

He will unite closely and intimately with those that are not the same. However he would not conceal any longer the that sexual relationships he carries on with those who are like bim, and with whom he lies down.

Ik licht er kort twee passages uit:

"Hij zal sexuele affaires aangaan en gepreoccupeerd zijn met het lichaam en de vleselijke noden. Hij zal gumsten en giften verlenen aan hen die aan hem toebehoren."

"Hij zal dicht en intiem samenkomen met hen die niet zijn als hij. Maar hij zal niet langer de verboden sexuele relaties, die hij met anderen als hem heeft, verbergen."

Op de van hem bekende manier heeft Mintzberg $(1997,602)$ dit niet over zijn kant laten gaan. In een elegante en gemengd kritische en prijzende reactie op het onderzoek van Calás en Smircich knipt hij woor hen wan't zelfde laken een pak. Alhoewel hij het niet eens is met hun verleideligke transformatie van zijn visie op leiderschap, onderschrift hij dat ze gedrieen wel met hun schrijuen willen verleiden "For we have both set out to seduce our reoders, have we not ....?"

Afsluitend vat hij hun aanpak samen in een sexgetint, intrigerend grapje. Het gaat over een man die naar de psychiater gaat en op elke Rorschachvlek, die hem wordt getoond, reageert met ".. dat zijn twee mensen die, nou ja, ontucht plegen met elka ar!" Na een paar van deze reacties stopt de psychiater en zegt "U bent de meest sex geobsedeerde man die ik ooit ben tegengekomen!" "Sex geobsedeerd? Ik? Wie laat mij hier telkens van die smerige plaatjes zien!" 


\section{Management en organisatie als literair genre}

Is de lezing wan Calás en Smurcich van de vier klassieke leiderschapsteksten als "werleiding' meer war dan die als 'leiderschap"? Meer waar dan .. des schrijuers bedoeling? Zo wraagt Barbara Czarniawska zich af: Ja en neen dus.

Mintzberg (1997) in zijn licht geagiteerde reactie op hun benadering verwerpt "leiderschap als werleiding, maar valt zelf wel terug op "schrijven als verleiding. Als lezers zich zouden moeten beperken tot de bedoeling van de schrijuer, dan zouden we het met $z$ 'm allen niet ver brengen. Gelukkig maar voor schrijvers en lezers dat schrijvers meer schrijven dan ze weten (Czarniawska, 1999, 91).

Caarniawska pleit op goede gronden dat romans een interessant model en opzet kunnen zijn voor management en organisatie theorieen, net om romans te imiteren, maar om je erdoor te laten inspireren. Met name het vermogen van creatief inzicht en niet zozeep documentaire precisie maakt de roman een potentiele concurrent van en een discus. siepartner voor organisatie theorieen.

Zo hebben detective verhalen en organisatie studies een woorkeur gemeen woor een realistische stij!, met een scherp oog woor het sociale leven. Beide focussen op het oplossen van problemen in een sociale context, met als hoofdpersonages de detective respectievelijk de consultant.

Een tweede analogie tussen beiden is de verhaalstructuur. De plat van een detective roman bestaat uit twee verhalen: dat van de criminele daad "die (nog) verborgen is en word ontsluierd door het tweede verhad. dat van het onderzoek of het verwerven van kennis. Dat blijft voor de lezer lang verborgen omdat je wat de detective doet pas begrijpt als het eerste verhaal duidelijk wordt, en soms zelfs net daarna. Voor beide genres geldt wat wel wordt genoemd een 'logic of discovery' (Czamiawska, 1999.79-80).

Ook Latour (1996) en Goodall (1994) stellen serieus en met succes voor om de twee genres: fictie en sociale theorie in elkaar te laten overlopen als éen hybride genre. Dat gebeurt al en met name in executive education. Als de grote, postmoderne verhalen van vooruitgang en emancipatie niet meer op gaan, ontstaat er immers ruimte voor de 'klei. ne., wat de wezensworm is wam werbeeldingrijke inventiviteit, vooral in de wetenschap (Czamiawska, 1999, 95). 


\section{Leiderschap: wie (ver)leidt wie?}

In wat voor richting een schip ook beweegt, de stroom van goven die het door het water snijdt, ligt er altijd aantoonbaar woor.... En ongeacht waar het een draai maakt, er ligt altijd weer een golf voor, anticiperend op zijn beweging...

Waar het schip ook heen mag gaan, de stroom van water, die niet stuurt noch versnelt, schuimt ervoor uit. van een afstand gezlen lijkt dat stromend water helemaal wit zich zelf te bewegen, en meer nog het water lijkt richting te geven aan de bewegingen wan het schip (Tolstoy. 1991, 1289).

Leiders staan vóór degenen waraan ze leiding geven... maar er hangt als mysterie omheen de kwestie of ze trekken aan of geduwd worden door hen, die achter hen (of is het vóor hen) staan?

Kafka's parabel over de chinese muur toont de behoefte van mensen aan leiderschap, die zin geeft aan hun bestaan en in hun hoofd zit, zonder dat ze de leider ooit gezien hebben en zonder dat die eigenlijk -als mens- hoeft te bestaan. De teider of chinese keizer als begrip bestaat dus wel degelijk, ongeacht of en hoe de mens "keizer" bestaat. De muurbouwers weten het, maar ze zwijgen. De chinesen bouwden de muur omdat ze vermoedden dat een keizer dat ooit bevolen kon hebben. ze bouwden verder omdat ze deden wat ze altijd al deden. het was er altijd al geweest. zo ook het leiderschap (Ten Bos, 1998, 98-99)

Leiderschap is een uiterst relevante zingeving aan het bestaan, terwijl leiders pas kunnen bestaan als de omstandigheden ernaar zijn, als die hun de gelegenheid geven die gedaante aan te nemen.

Martin Luther King gaf ooit aan dat de Martin Luther King, zoals de mensen hem zagen, hem zelf wolledig onbekend was. Die zelf-observatie illustreert fraai dat de 'leider' moette kan hebben zijn leiderschap te (her)kennen. Het zijn vrijwel steeds de omstandigheden, de ontstane behoefte aan leiderschap, die cen leider belangrijk maken.

Ten Bos benoemt ditt treffend: "... leiderschap gaat vooraf aan de leider. Leiderschap heeft geen leiders nodig. leiders kunnen niet zonder leiderschap. De leider is de nasleep van leiderschap, niet omgekeerd." "Ten Bo5, 1998, 100).

Doen niet veel mensen net alsof leiders miet bestaan, ze kunnen ze best wel missen, terwijl op andere momentery de behoefte groeit aan 
leiderschap. Wie dan precies opduikt als leider maakt eigenlijk niet zoveel uit. Dat kan in beginsel ledereen zijn. Misschien verklaart dat wel warom er zoveel verschillende leiderschapstheorieën zijn, als men leiders die ontstaan qua kenmerken verwart met de dan ontstane behoefte aan leiderschap.

Leiderschap is dus een mythe, beter nog een een sociaal verdedigingsmechanisme dat wil zeggen inensen projecteren hun problemen, angsten en zorgen op een leider, in de hoop dat hij/zij er meer aan kan doen dan zijzelf. Dat zijn de momenten waarop men werlangt naar leiderschap.

De behoefte aan leiderschap is als een psychologische gyroscoop, een kompas en vliegwiel (altijd op het noorden gericht) dat zorgt voor stabiliteit, en dat men op koers blift (Ten Bos, 1998, 108).

Paradoxaal is dat heden ten dage geen samenlevingen 20 geobse deerd zijn met leiderschap (sterk leiderschap, let well) als democratische samenlevingen.

Ten Bos parafraseert Canetti, die heeft aangegeven dat het niet om de eigenschappen of het karakter van de koning gaat, maar om het feit of de mensen om hem heen beslluiten hem als koning te accepteren: "Leiderschap is niet zomaar iets dat door de leider aan de volgers wordt opgelegd, leiderschap is vooral lets waarvoor die volgers zelf kiezen." (Ten BOr, 2001, 224). Wordt de koning ziek en raakt het volk in de war, dam is het beter de koning in stilte te wurgen. Dat gebeurt niet meer in de moderne tijd. Of toch wel iets daarwan? Zie wat De Volkskrant een paar maanden terug schreef over een president, die ergens zweefde tussen dood en kerngezond:

President Hejdar Alfev van Azerbeidzjan - is hy stervende of voett hy zich alken net zo lekker Hy is spinglevend, zegt de regering in Bakoe HII to goed als dood nenen oppositieportien

Wie er ook gellk heeft, het gesteggel over de toestand van de 8g-jarige president kent veel overeenkomsten met het gesluierde nieuws dat ty dens de ladste dagen uan andere sterke mannen naar buiten kwam Mao, brezjnev, Franca, hto naarmate de tid vorderde, werd de informa tie over hun welzin steeds schaorser Als een autocrabl op sterven ligt, moet er kennelik veel geregeld worden, 2 in opvolging bijwoorbeeld Tot die tha wordt er heel mysterieus gedoan en wordt zin leven gerekt 
De gang van zaken Jikt op die jond het oventjuen van sovje president Leonid Brezjnev in 1982 De ziekten die Brezhev troffen waren sinds 1974 gehem hetgeen een geruchtenstroom op gang bracht hif zou ljalen aan leukemie, koakkanker, doofheld en harklochten. Volgens het Kremin stierf de kettingrokende Brezjnev op io navember een plolselinge dood moar de bevolkng wist beter

De Spaanse dictator franco (overleden op 20 november 1975 ) had abnvankelik griep, noar bleek loter getroffen door een hantaanval en een moagbloeding, warna zyn toestand to h weer gestabllseerd was 20 ging het op en neer tot hy op 82 garige leeftid het loodle legde.

De loegoslavische president losip Braz Tto leejde 4 mel 980 zogenaamd nog toen hil al dood was. Nag een half wh na het verschjden van Who werd een medisch bulietin uitgegeven warin zijn toestand "kntiek werd genoend?

Charismatisch leiderschap wordt in elkar gezet, niet eens zozeer door de leider of zijn helpers, maar door wat wordt gedacht en verwacht. door de volgers Charisma is dus relatiegebonden.

crint geeft dit feilloos weer: "Wat telt in een charismatische relatie, is niet wie de leider is, maar hoe de mensen de leider zien. Men zou zelfs het charismatisch element geheel kunnen schrappen. Het punt is dat er zonder volgers geen leider is" (Crint, 1995, 135).

Charisma of het scheppen van een sociale relatie tussen leider en volgers gebeurt zowel door de leider als door de volgers. De mensen moeten de leider ook willen zien als een leider. Waarom iemand een groot leider is kan als raadsel alleen opgelost worden door goed te kijken naar de relatie tussen leider en volgers.

Hoe dichter je tot een leider nadert, hoe minder je hem als zodanig zult ervaren (Ten Bos, 2000, 113). Het facinerende van de leider ligt niet zozeer aan de leider, maar veeleer aan onze eigen behoefte a an fascinatie.

Daar zijn tegenwoordig ook de politieke campagnes op gebaseerd. 2 e kumen het niet stellen zonder verleiding. Sinds de tijd van John F. Kennedy gaat het vooral om charismatische uitstraling. Die zit zelfs al in de afkorting IFK. De huidige tegenkandidaat van Bush, John F. Kerry hoopt er zijn voordeel mee te doen. Met een fascinerende presentie willen ze de aandacht wan het publiek aan zich binden. Ze leren voortdurend van de manier warop de filmwereld en andere media tekens opnieuw sterren en idolen creëren. Fascinatie en verleiding zinn dan sleutelbegrippen $(\mathbb{R}$. Greene, 2001,19$)$. 
Zodra men inzoomt op leiders, des te meer zwaktes en gebreken kunnen bliken. Men krijgt dan meer oog voor wat de leider kan ondermijnen. Maar wat weten we eigenlijk over leiders. leder die het van dichtbij bestudeert kan dat niet benoemen of invullen. Er bestaat niet eens ondanks het zeer vele geschriff erover - een stabiele 'body of knowledge.

Volgens.Huczynski lijden we onder twee mythes: die van de leider als de grote man en die van de leider als belangrijk voor het presteren van een organisatie. Met name de laatste idee lijkt vooral projectie. Volgens Huczynski hadden schrijuers als Mcoregor en Likert door dat managers behoefte hadden aan zo'n mythe, maar uiteraard ook de mensen (Huczynski, 1993, 88).

Als ze al een bijdrage hebben dan is het in de mogelijkheid om de organisatiecultuur te kunnen/willen beinwloeden, alhoewel meerdere auteurs daar ook sceptisch over zijn. Schein (1985) bepleit een rol in het vooroplopen in waardegerichtheid d.w z. walar het in een organisatie echt over hoort te gaan. Veel contact met de dagelikse gang van zaken in de organisatie of het bedrijf is dan belangrijk. Leiders kumnen dan (als ze de organisatie dynamiek snappen, helpen om als een soort architect voorwaarden te creéren voor een duidelijke visie en goede organisatie. Nochtans mag niet vergeten worden dat waar het bij een organisatie omgat en wat de achtergrond is van de werknemers minstens zo bepalend is voor de cultuur.

Maar dan doen toch weer sommige leiders ons wel degelijk veranderen en geven ze betekenis aan de manier waarop hun volgers of ondergeschiktern tegenover de wereld staan, respectievelijk aan het beeld dat ze ervan hebben. In de praktijk ontstaat er zo een andere manier van kijken naar wat men doet, "t krijgt een ander gezicht. Beroernde schilders of beeldhouwers, maar ook dichters creëren nogal eens zo'n andere. nieuwe manier van naar de werkelijkheid kijken en een andere manier van har te kennen.

Zo'n leider zegt niet hoe het is'; hij vertelt zoals't kan zijn en geeft 't een ander gezicht... de leider is een zin-en betekenisgever. Hij/zij is dan ook de verpersoonlijking, die helpt om te ontsnappen aan wat anders voor velen niet te omvatten is, wat anders een chaotische, omverschilige of onverbeterbare wereld lijkt te zijn, waarover we niet echt controle hebben (Weick, 1995, 10). 


\section{Leiders zijn zingevers, ze maken er wat van}

Het hedendaagse onderzoek naar leiderschap is het best te positioneren door te kijken naar twee typische verschillen. Wat is de rol van het individu, anders dan die van de situatie of de context? En twee, is er wel of niet een 'objectieve' of duidelijke verklaring voorhanden voor de ver. schijnselen waarom het gaat. Dit tweetal verschillen tegenover elkaar gezet resulteert in vier typen of theorieern over leiderschap. Situationele theorieen, waarin het leiderschap volledig wordt bepaald door de situatie of de omgeving. Contingentie theorieen, waarin beide, individu en omstandigheden, even belangrijk zijn c.q. op elkaar inspelen.

De derde categorie theorie focust daarentegen louter op de leider als persoon, er zijn geen bijzondere omstandigheden, met als gevolg dat in. het- $\circ \mathrm{g}$-springende kenmerken van dat individu de theorie bepalen. Bij de vierde categorie, die naar mijn idee het meest woorkomt. ligt het accent niet op enig specifiek individu noch op bepaalde, bijzondere omstandigheden. Het leiderschap van $x$ of $y$ wordt in de situatie of onder de geldende omstandigheden geconstitueerd. Er lijkt dus vooral sprake van constitutieve theorieèn (Grint, 1997, 2-10).

Erop vertrouwen dat het leven de moeite waard is leidt tot gedrag dat het vervolgens ook de moeite waard maakt. Wat men denkt of meent wordt tastbaar door te handelen naar't vertrouwen dat men erin heeft. Mensen moeten net doen alsof alles echt bestaat. Dat is in essentie het idee van leiderschap. De Hongaarse Nobelprijs winnaar Abert Szent-Gyortillustreert dat treffend met een voorval, dat plats had bij militaire oefeningen in $\mathrm{Zwitserland.}$

De jonge luitenant wan een kleine Hongaarse eenheid in de Alpen stuurde een verkenningspatrouille de ijzige wildernis in. Aanstonds begon het wel twee dagen lang hevig te sneeuwen. De patrouille keerde niet terug. De luiteriant was zeer benauwd dat hif zin mensen de dood in had gestuurd. Maar op de derde dag keerde de patrouille alsnog weerom. Waar waren ze geweest? Hoe hadden ze de weg terug gevonden? Ja, zeiden ze, we dachten zelf ook dat we verloren waren en wacht ten op het einde. Tot een van ons een kaart in zijn bepakking vond. Dat stelde ons gerust. We sloegen kamp op, zaten de sneeuwstorm uit, en met de map hervonden we onze orientatie. Hier zijn we. De luitenant: bekeek de landkaart eens goed en ontdekte tot zijn verbazing dat het niet een kaart van de Alpen, maar eentje van de Pyrenceen was. 
Dit voorval latat zien dat als je verdwaald bent, elke oude kaart bruikbaar is. Projecteer dat nou eens op strategie. Misschien kan, als je "t niet meer ziet zitten, elk oud strategisch plan nog wel helpen. Strategische plarimen lijken immers veel op landkarten. Ze bezielen en geven mensen orientatie. Zodra mensen beginnen te handelen, ontstaan tastbare uitkomsten in de ene of andere context. Die helpen dan om uit te vinden wat er gaande is, wat toelichting behoeft, en wat vervolgens moet gebeuren.

Managers vergeten al snel dat het gaat om wat ze doen, en niet om wat ze plannen, wat bepaalt wat succeswol is. Ze blijwen vaak waarde hechten aan de verkeerde dingen, zoals een plan. Maken ze zon fout, dan spenderen ze vervolgens meer tijd aan het plannen dan aan wat er moet gebeuren. En dan zijn ze ook nog eens verbaasd dat meer planning niks werbetert en miet helpt (starbuck, 1993).

Natuurlijk is het beschreven voorval in de Alpen des te interessanter als de leider van de verdwaalde patrouille had geweten dat het de verkeerde landkaart was en toch in staat was geweest om zijn mannen terug te brengen. Dat illustreert aardig de situatie, waarin de meeste leiders zich bevinden. Ondergeschikten zijn vaak verdwaald en zelfs de leider weet niet waarheen. Alles wat leiders weten is dat hun plan of hun landkart niet goed genoeg is om eruit te komen. Wat de leider in zo'n situatie moet doen, is de mensen vertrouwen geven en ze aan de gang krijgen, de ene of andere kant op. Vervolgens moet men goed letten op aanwijzigingen of signalen als gevolg van het eigen gedrag om er zo achter komen waar ze waren, en om een wat beter idee te krijgen van waar ze zijn en waar ze willen uitkomen.

De soldaten konden een goed resultaat boeken met een slechte kaart ondat ze in actie kwamen, ze hadden een doel (terug naar het kamp) en ze hadden een beeld van waar ze waren en waar ze naar toe gingen. Ze bleveri doorgaan, ze bleven signalen opvangen, en ze bleven steeds bijstellen waar ze zich bevonden. Met als gevolg dat een ondeugdelijke kaart toch goed genoeg was. De signalen en tekens die ze oppilkten en waarnaar ze bleven handelen gaf temidden van de onzekerheid vertrouwem, en dat zette weer zingeving in gang. Eenmaal op gang, zal zulke zingeving al snel het vertrouwen bevestigen omdat het effect ervan immers hard is, terwijl er daarvoor alleen maar over gedacht kon worden (Weick, 1995, 54-55). 
De vraag is zelfs of een intelligent "executive" igenijk wel een wolledig accurate waarneming nodig heeft. Het is alleszins mogelijk dat onjuiste percepties, onder bepalide omstandigheden, wel degelijk kunnen leiden tot positieve gevolgen. Mispercepties als de zaken stevig vastzitten of niks bereikbaar lijkt, kunnen toch aanzetten tot proberen, tot risico nemen enz. Het hebben van een juste kaart is dan minder belangrijk dan een kaart die een beetje uitzicht biedt en aanzet tot actie (Sutcliffe, 1994.1374).

Het is vaak belangrijker om althans enig idee of interpretatie te hebben en te beginmen dan maar af te wachten, en niks te doen tot dat "de" verklaring opduikt. Niet in het minst omdat, zeker in het bedriffieven, tijd geld is Exact weter wordt dan liever ingeruild woor snelheid van handelen respectievelijk voor onmiddellijk reageren.

lets te kunnen doen beimwloedt warin men well of niet gelooft. Zin maakt wat wordt geloofd als gevolg van wat gebeurt. Exactheid is niet eens het punt.

Accuraatheid is aardig, maar niet per se nodig om zin en betekenis te geven. Maar wat is dan wel nodig?

Het antwoord is eenvoudig en ingewikkeld tegelijk: iets dat zorgt voor plausibiliteit en samenhang. iets dat redelijk en waard is om te onthouden, iets dat worm geeft aan eerdere ervaringen en aan verwach tingen, iets dat anderen aanspreekt, iets warmee je kunt terugblikken maar ook vooruitkijken, iets woor "t gevoel maar ook om over na te denken, een soort kader dat past op al die hedendaagse gekke dingen, en iets dat leuk is om in elkaar te zetten. Al met al, wat nodig is voor zingeving is een goed verhaal. Zingeving gaat over plausibiliteit, samenhang en redelijkheid. Het gaat dus om geloofwalardige en sociaal acceptabele verklaringen (Weick, 1995, 61). 


\section{Een vrouw als leider, vergeet alles!}

Zodra mensen denken de wereld te begripen, de betekenis van de wereld doorzien, dan is die betekenis al weer gedateend. Als mensen 'zien wat ze zeggen' om te weten wat ze denken, dan is wat gezegd is al geschiedenis tegen de tijd dat het wordt begrepen Maar ook, als mensen vasthouden aan wat ze denken nadat ze zien wat ze zeggen, dan worden die vastgehouden gedachten gedateerd omdat gebeurtenissen door zijn gegaan. Wat men denkt zal dan minder voor zich spreken dan het voorheen deed.

Gelukkig veranderen veel dingen niet zo snel dat wastgehouden kennis gelijk waardeloos wordt. Daarin ligt de spamming. Vastgehouden kennis is dus deels een heel bruikbare gids voor de toekomst en anderdeels misleidend. Om effectief te begrijpen of ergens betekenis aan te geven is moeten mensen dus tegelijkertijd geloven in, zowel als twijfelen aan wat ze weten. Idealiter moeten mensen zo handelen dat ambivalentie het optimale compromis is.

Caraline Paul was een van de eerste wrouwelijke brandweerlieden, die werd toegelaten tot de millitante (overwegend mannelijke) brandweer van San Francisco. Ze vertelt wat er gebeurde toen ze woor de eerste keer de brandspuit mocht aanvoeren en een team mee naar binnen nam in een fel brandend gebouw. Binnen was de rook zo dik dat ze haar eigern hand niet meer kon zien toen ze die tegen de bril van har luchtmasker duwde. Als haar ploeg zich zo het gebouw binnenworstelt zonder enig zicht, wertelt zij wat vervolgens gebeurde:

"Met het stellige voomemem om zelf de vuurhaard te vinden, loop ik ergens met mijn knieën tegenaan. Om de een of andere reden, besluit ik dat dit een trap moet zijn, en ik stap erop. Ik probeer nog een stap omhoog, maar ik stoot weer tegen iets op, voor me. Dat moet natuurlijk een klein verhoog zijn. Ik stap omhoog en pers me naar woren om me zo door het gat te wringen. En weer klap ik ergens tegenaan, mijn voet vindt geen tree. Doorzettend, duw en wring ik nog een keer, én nog een keer, terwil mijn hoofd hard, elke keer weer tegen iets a an bonkt. Dit gebeurt allemal razend snel, en dan woel ik ineens een hand die aan mijn jas trekt lemand is achter mij. Die hand, alleswetend en nar het lijkt allesziend (of waarschijnlijk, gewend aan niks te zien) leidt me naar links en we kruipen omlaag naar wat een gang moet ('t moetl) zijn. De hitte neem toe Scheuten van licht flitsen op woor ons" (Paul, 1998, 86). 
Niet lang daarna gaat het alarm van Caroline"s luchtfles af, wat betekent dat haar luchttoevoer erg la achter haar, en volgt de slang terug het gebouw uit omeen nieuw lucht. fles te halen. Tegen de tijd dat ze het gebouw weer ingaat, is de rook opgetrokken en hebben de ruimten weer vorm gekregen. Als ze hav stappen van daarstraks nagat vindt ze de trap die haar zoveel moeite kostte.

Zo beschrijft ze die gewaarwording:

"In één oogopslag zie ik dat het geen trap naar een ve hoog is waarop ik me bevond. In plaats daarvan, in een hoek even verderop, staat een enkele stoel tegen de muur gepropt. Ik slaak een enorme zucht, Jezus Christus! Daar was ik dus bezig, op een stoel ik stapte niet op een verhoog, ik stond tegen "n muur te bonken. Op dat moment was ik dus een gedesorienteerd rund. ik was Don Quichote, die een windmolen voor ridder aanziet; ik kwam uit de Middeleeuwen, natuurlijk, natuurlijk die lijn aan de horizon geeft aan dat de wereld plat is. Veel te snel oordelen. denk ik! Dank de heer voor het pikkedonker. Niemand anders, zelfs die ene hand kan me bezig hebben gezien" (Weick, 2001, 87).

De moraal die Caroline Paul aan har ervaring verbindt is de volgende: "In de komende jaren moet ik me steeds weer inprenten dat een erwaren brandweervrouw alle vooronderstelde beelden moet dumpen; die spelen alleen maar spelletjes met je in het donker. in plats daarvan, moeten haar geest en lichaam volkomen open, flexibei, soepel en plooibaar blijven. Wanneer je ergens tegen aanloopt, hoeft dat beter nog. moet dat niet benoemd worden (tafel, stoel, bed?) of moet er niet omheen of doorheen gelopen willen worden, klein pumt maar toch belangrijk. Als je denkt dat je tegen een tafel aangelopen bent dan zul je er ook omheen willen lopen als om een tafel. Maar als het in plats. daarwan een bed biijkt. dan zul je tegengehouden worden door dit grotere, moeilijk verplaatsbare object. Er omheen lopen of het oprij dwwen zal niet lukken. ledere brand is een nieuwe ervaring" (Weick 2001, 85).

Waar Caroline Paul tegenaan is gelopen en over gestruikeld, is de gewaarwording dat wat ze "weet' haar kan opbreken, Betekenis, dat wat iets is, is een samenspel van taal, verbeelding en gedrag zoals dat werkte in het verleden, maar daarmee nog niet noodzakelijkerwijs in de toekomst. De taal van "tafel', 'stoel', "bed' of 'trap omhoog" klopte voor Caroline in het verleden, toen haar zicht miet werd gehinderd en loen de gevalgen ervan niet levensbedreigend waren. Maar in de hedendaagse 
wereld van het bevechten en blussen van branden in steden. waar weemde dingen en voorwerpen ondoordringbalar door de rook je kunnen misleiden, en war wammen plots over de hoofden heen van de birnendringende brandweerlieden kunnen uitbarsten, is een 'betere' taal voor wat je denkt en wat je doet de taal van iets waar je langs moet zien te komen'. Geest en lichaam blijwen meer open en flexibel wanneer mensen, althans mensen die vuur bevechten, uitgaan van meer algemene betekenissen dan met het specifieke van verkeerd benoemde abjecten.

Natuurlijk is het verleden geen wijand van de toekomst, omdat er altijd wel lets van aanwijzingen nodig is om een bepaald gedrag in te zetten. Wat opvalt bij voortgaande betekenisgeving is dat aanduidingen uit het verleden gemengd moeten worden met alertheid woor de niet routine van het heden; Eigenlijk moet je je gedragen alsof wat je weet, waaraan je je vasthoudt, zowel waar als niet waar is, zowel plausibel is als niet voor zich spreekt, een combinatie dus van weten en onbekendheid. Hoe meer je weet, hoe meer je ontdekt dat je niet weet.

De complexiteit wan herinneringsprocessen maakt betekenisgeving een gevechl om 'alertheid'. Het gevecht gaat om de verleiding te weerstaan om ongebruikelijke gebeurtenissen te normaliseren, de verleiding om te zoeken naar bevestiging in plaats van dat te laten. De verleiding om zich te voelen als alles al ervaren te hebben en dat er geen verrassingen meer zijn. De premie op het hebben van 'agressief zelfvertrouwen' onderdrukt veel te snel alertheid en versterkt de neiging om steeds weer dezelfide vertrouwde betekenis over een veranderende wereld heen te leggen. 


\section{Verlangen naar wijsheid (ver)leidt tot ambi- valentíe}

Wanneer mensen een kaart van een onbekende en onwoorspelbare wereld moeten maken, dan vechten het zelfverzekerd weten en overdreven voorzichtigheid om woorrang. Wijsheid bestat uit een houding (of attitude) tegenover de eigen opvattingen, waarden, kennis en informatie die zich tegen de verleiding van het een boven het ander plaatsen verzet, door middel wan het voortdurend balanceren tussen weten en twijfel.

Weick (2001) heeft de thematiek van wijsheid als houding ontwikkelt a an de hand van indringende studies van enorme bosbrander en andere brandweerrampen. Op grond van een eerdere observatie van hem bif de zogenoemde 'Mann Gulch Wildfire' ramp, hebben brandweerlieden zijn analyse en benadering overgenomen in hun trainingen.

linmiddels hebben brandweerlieden gaandeweg grote wijsheid ontwikkeld, die ook is vastgelegd in verschillende specifieke gedrags-en houdingsregels.

Weick's eerdere observatie bij die grote bosbrandramp was dat de brandweerlieden in de vuurval waren komen te zitten doordat ze zich er veel te zeker van woelden dat ze de brand tegen 10:0ou de volgende ochtend onder controle zouden hebben. omdat ze die eigen zelfverzekerde opvatting niet als potentiëel fout konden zien waren ze ook niet in staat om meer en meer signalen op te pikken dat de vurzee zou kunnen gan exploderen.

De brandweer leidinggevenden bij natuurbranden zijn begonnen als grondregel te volgen: "Geef een brand nooit over aam een andere ploeg op het heetst van de dag." Het gaat er hierbij om dat wanneer een vertrekkende ploeg een brand overdragt aan een nieuwe ploeg, dan moeten ze dat doen wanneer het 't makkelijkst is woor de nieuwe ploeg te begrijpen wat er aan de gang is, in te stappen en de strategle voort te zetten van de vertrekkende ploeg. De beste overdrachtstijd is 's machts met meestal weinig wind, hoge vochtigheid en lagere temperaturen. Branden stabillseren dan wat en zijn beter voorspelbaar (Weick, 2001, 361).

Het maxim of de grondregel wan "het heetst van de dag" is belangrijk als illustratie van twee vitale kenmerken van wijsheid: reflectie en oordeelsworming ("judgment"). 
Reflectie is het best te zien als de gewoonte om voorvalien en opvattingen te bezien in het licht van hun oorzaak en gevolg. Reflectie gaat wooral over de inhoud of substantie van wijheid, terwijl oordeelsvorming slat op thet proces van wijsheid. oordelen is de wijsheid van doeleinden, oftewel de inschatting en het kiezen van waarden, intrinsieke goederen en doeleinden (Blanshard, 1967,323).

Het advies om brandbestrijdingsoverdrachten op het heetst van de dag te vermijden weersplegelt "t gisse bewustzijn dat zelfs een relatief' kleine gebeurtenis bij de complexe mobilisering van hulpmiddelen, die nodig zijn om een groot wur te onderdrukken, van grote invloed kan zijn op het succes of falen van de missie. Het spreekt niet woor zich dat als een vermoeide ploeg een brand verlaat en wordt verwangen door een nieuwe ploeg, de zaken dan slechter zullen gaan. Van de levering van nieuwe hulpmiddelen zou men eerder een verdubbelde inspanning en sneller succes verwachten. De grondregel warschuwt de mensen ervoor dat precies het omgekeerde ook kan gebeuren. Die waarschuwing vooraf is een teken van wijsheid, vergemakkelijkt door goed oordeelsvermogen waarmee het belang wordt onderkend wan onverwachte situaties (Neick, 2001, 364).

Het is wijs om alert te blijven op de steeds mogelijke feilbaarheid wan het weten door ën le letten op mogelijk faler en actief te twijfelen én te letten op wat men weet en dat actiefi te bevestigen. Wijs zijn betekent gewoon doorgaam, wetend dat wat je weet kan falen en dat wat je ook doet vorm geeft aan wat je tegenkomt.

Wijsheid is een denkkwaliteit die wordt gedreven door de dialectiek dat hoe meer men weet, des te meer men zich realiseert hoeveel men niet weet.

Het idee dat wijsheld veel meer een houding is dan louter denken spreekt daarom aan omdat het inhoudt dat mensen hun kundigheid om wijs te handelen dus kunnen verbeteren.

Brandweermensen moeten bijvoorbeeld kunnen zien wat ze niet weten, omdat het anders hun leven kan kosten. Maar ze moeten ook wol vertrouwen blijven on de moed op te kunnen brengen een brand te lijf te gaan en neer te slaan. Twijfelen en aarzelen laat gebeurtenissen onomkeerbaar uit de hand lopen. De verantwoordelijken bij de strijd tegen natuurbranden moeten zowel vragen blijven stellen alsdat ze 
moeten handelen alsof ze de meeste antwoorden al kennen. Hoe kunnen mensen - ook in andere, soortgelijke hoog tempo settings - simuttaan weten en twijfelen (Weick, 2001, 367).

Beoordelen van belangrijkheid neigt negatief te correleren met oordelen over niet-weten. Als ik het niet weet dan is het warschinlijk niet belangrijk of zelfs mogelijk niet waar. Mensen hechten alan oude ideeen en neigen er naar nieuwe eraan aan te passen. De combinatie van hard. nekkige, oudere "waarheden" en de neiging om nieuwe ideeen aan de bestaande aan te passen, leidt vaak tot de opvatting dat wat men weet ook dat is, wat waar is. En als het waar is, waarom er dan aan twijfelen? (Weick, 2001, 368).

Topmensen kunnem hun onwetendheid negeren door de manier walarop de meeste organisaties zijn ontworpen. Het centraal in netwerken plaatsen van execultives bevordert de misvatting van centraliteit: "Als dat zo zou zijn, dan zou ik er zeker van hebben geweten, maar omdat ik er niks van weet, bestaat 't ook niet." Bovendien, hun succes met het creëren wan gebeurtenissen, het continu krijgen van ondersteunende informatie en hun zoeken, onder druk en hast, naar bevestigende voorvallen onderstreept hun notie dat ze 't meeste weten van wat er te weten valt. Er is dus woor hen geen enkele aanleiding om aan hun kennis te twijfelen. Als we aan deze organisatorische dynamiek nog eens die van anticiperende socialisatie toevoegen (dat wil zeggen dat mensen lager in de hierarchie die hogerop gaan nadoen), een cultuur die de waarden van het topmanagement weerspiegelt, en constante druk op resultaten meer dan op reflectie, verbaast het niet dat overmoedigheid vrij normaal is in organisaties en dat een houding van wijsheid nogal zeldzaam is. Niet alleen is wijsheid zeldzaam, er is ook geen aansporing om het alsnog binnen te halen.

Als men ergens lichte aamwijzingen woor heeft (men heeft zich nog niet gecommitteerd) dan is dat een richting om te volgen, en dus nog niet een beslissing, die verdedigd moet worden. Het is makkelijker om van richting te veranderen, dan een beslissing te herzien, want er stat minder op het spel. Een soortgelijke reflexiviteit en flexibiliteit wordt gedemonstreerd op het slagveld, waar commandanten soms "ernpirisch vechten" orn zo te ontdekken wat woor soort van vijand men tegenover zich heeft (Isenberg, 1985). 
Hoe hoger men komt in organisaties, hoe meer zelfverzekerd men wordt door het filteren van informatie. Met zelfverzekerdheid komen echter ook blinde vlekken, crises, dingen uit angst voor gezichtsverlies kleiner maken dan ze zijn, die allemaal de aandacht voor de gevolgen van overmoed aan de top afleidt. Als organisaties hun onwetendheid negeren, dan menen ze dat de daarmee vaak gepaard gaande arrogantie ook nog eens goed management is. Als dat gebeurt, dan zou wijsheid pas echt het laatste concurrerend voordeel kunnen zijn. Vooral omdat "t zo moeilijk te dupliceren is (Weick, 2001,371).

"De omvang van wat we denken en doen wordt beperkt door wat we niet in staat zijn te zien. En omdat we niet in staat zijn te zien dat we falen dat op te merken is er weinig dat we kunnen doen om te veranderen, tot dat we zien hoe ons falem te zien onze gedachten en daden vormen" (Laing, in: Mangham \& Pye, 1991، 31).

Improvisatie is niet 'iets maken uit niets'. In plaats daarvan, gaat het om iets te maken uit eerdere ervaringen, wit de praktijk, en op die momenten te weten dat men het intuitief begrijpen van eerdere gebeurtenissen aftast en test, terwijl tegelijkertijd wat er gebeurt nog steeds kan veranderen. Geloof in de kracht van improvisatie versterkt een houding van wijsheid.

Improvisatie maakt het mogelijk dat mensen zich in situaties begeven met feilbare kennis, en zich daarbij op hun gemak voelen omdat ze denken dat ze die kennis weer opnieuw kunnen combineren en door waar ze slecht in zijn te laten lopen. Vertrouwen in hun vermogen om er altijd wel lets van te kunnen maken stimuleert het zelfvertrouwen in lhun persoonlijke balans tussen weten en twijfel. Door ervan uit te gaan dat wijsheid een houding is die weten en twijfel in balans houdt, laat dat een nog fundamenteler aanpassingsprincipe zien, namelijk dat ambivalentie het optimale compromis is.

Dat ambivalentie het optimale compromis is, valt goed te illustreren aam een ander aspect van het bestrijden wan natuurbranden, namelijk in het ontwerp van hoe men een brandweer ploeg opstelt. Zo'n ploeg mag pas dan een brand bestrijden wanneer de ploeg voldoende uitzicht heeft, de communicatie verbindingen werken, ontsnappingsroutes (tenminste twee) bekend zijn en veiligheidszones zijn gecreëerd en wanneer iedereen dat ook weet. Het hebben wan uitzicht en de communicatie mogelijkheden impliceren dat de ploeg steeds weet wat er gebeurt en 
hoe de locale condities samenhangen met het bredere beeld. De aandacht voor ontsnappingsroutes en weiligheidszones betekenen daarentegen dat wat de ploeg weet incompleet kan zijn en dat men tegen dit potentiele niet-weten beschermd moet worden. De ploeg is dus simul. taan vol vertrouwen én voorzichtig. Dat is mogelijk omdat ze erop vertrouwen in staat te zijn dat wat ze weten bijeen te brengen en opnieuw te combineren. De ontsmappingsroutes en velligheidszones sluiten bij ploegen overmoed uit, terwijl het hebben van uitzicht en de verbindingslijnen bedeesdheid uitsluit. De combinatie van deze vier componenten bemoedigt een houding van wijsheid tegenover gevaar, zonder actie te belemmeren. Weten en niet-weten balanceren op het draaipunt van improvisatie. Het hele samenspel laat de ambivalentie van wijsheid zien en onderstreept de wijsheid van ambivalentie. 


\section{De verleiding van rationaliteit en funktiona- liteit}

Veel van de hedendaagse management theorieen worden helaas gedomineerd door een referentiekader met een duurzame ordening van ruimte, tijd en materie: Dat bepaalt het afgebakende - of beter gezegd: het beperkte - beeld dat men hanteert van de werkelijkheid. "...the belief that theories are attempts by the intellectual elites of society to accurateIy describe and represent reality as it is in itself. When this accurate mirroring is achieved, theories are then deemed to be true and hence carry the full weight of scientific, authority along with them. Univocality of assertion and, hence, universality of application is arrived at by systematically undermining and killing off competing views much in the same way militany strategist's maneuver to first isolate and then pick off opposing forces" (chia, 1996, 2-3).

Causaliteitsdenken en de toestand van rust bepalen wat normaal is en wat men vindt dat ook normaal hoort te blijwen. Bewegen is niet meer dan de overgang van de ene stabiele toestand naar een volgende. Verandering, beweging en transformatie zijn in die zienswijze slechts scharnieren en randwerschijnselem. Veel van het gangbare denken over ordening, management en kennis representeert zodoende een werkelijkheid die het zelf schept.

Anders en mijns inziens beter, is de opvatting dat alles stroomt en in beweging is en waarim alles steeds weer wordt en voortdurend ontstaat. "It is movement that we must accustom ourselves to look upon as simplest and clearest, immobility being only the extreme limit of the slowing down of movement, a limit reached only, perhaps, in thought and never in nature" (Bergson, 1913. 144). Als men wil uitgaan van het primaat van beweging en proces boven statische entiteiten en permanentie, dan heeft dat ingrijpende consequenties voor het verstaan en begrijpen van het proces van management, en voor de pedagogische agenda van management educatie.

Het idee dat management vooral te maken heeft met argebakende prestaties, warbij managementkennis koopwaar is, baseert zich op de wooronderstellingen van een zijns-ontologie ( 20 is het') en een representationele epistomologie ('. en dat zijn de kernislabels warmee we werken'). Zulk soort denken vertrouwt op wat men weet en warvan men weet. Daar staat tegenover de intellectuelle empathie, waamee 
men grip wil krijgen op wat uniek is en vaak nog niet goed is te verwoorden. Het cultiveren daarvan is van cruciaal belang om succesvol te zijn in een wereld, die toenemend meer wordt gekenmerkt door fluiditeit en voortdurend verschuivende en veranderende bedrijvigheid.

Toekomstgerichtheid en visie maeten echter tegetijkertijd zoveel als kan wortelen in de erkenning en beheersing van routines. Routines zijn van eminent belang. Ze bewijzen zich telkens als men zich eraan conformeert, er zorg aan besteedt en zonodig nieuwe ontwerpt. Maar accepteren en wertrouwen op routine is niet genoeg. Om succesvol te kunnen zijn als manager moet men ook het vermogen ontwikkelen om de voortgaande complexe variëteit in samenlevingen te begripen, grip te krijgen op trends en sociale bewegingen en in stat te zijn om zulke kwalitatieve veranderingen ook kwantitatiefin te schatten. Het is bij witstek de complementariteit van beide, de kracht van routine en de instinctieve greep op patronen van 'interconnectedness" die samen een adequate management visie funderen.

Die visie omvat dan een brede aanleg "... for eliciting generalizations from particulars and for seeing the divergent illustration of generalities in divers circumstances" (Whitehead, 1933. 120). Als men overeenkomsten kan zien in verschillen en werschillen in overeenkomsten dan kan men ook een bepaalde management situaties omkeren en herdefineren, want ".. the conduct of business requires intellectual imagination" (Whitehead, 1994, 99).

In termen van management educatie gaat het om een kritische en reflectieve houding tegenover de beelden wan de wereld. Processituaties moeten worden beleefd en uitgedlept zoals ze zich voordoen, zonder toe te geven aan de eerste verleiding te denken door te hebben waarom het gaat. In termen van leren vraagt dit om steeds open te blijven staan voor de ambivalentie en ambiguiteit van wat nog niet bekend is noch gekend wordt.

Een tweede wereiste is om te blijven doorzien hoe een situatie zich manifesteert, omdat dat bepalend is voor en wormgeeft aan zijn betekenis, interpretatie en sociaal belang. Bepalde uitkomsten of resultaten vergelijken met en onmiddellijk koppelen aan algemene causale facto. ren, zoals vak in gangbare verklarende modellen gebeurt, is weinig pro. ductief: 
contextuele kennis bepalend is woor het resultaat. Gaandeweg wordt duidelijk dat cen contingente, reflexieve en dus pragmatische managementbenadering vandaag de dag het meest effectief en waardevol is. Des te meer moet elke management situatie gezien worden als 'beladen' met hoe zij is ontstaan, met fouter, aanpassingen, goede en slechte inschattingen, maar ook met een reeks van mogelikheden op toekomsitge resultaten.

Hoe we een situatie begrijpen inspireert tot een specifiek soort van aanpak terwijl die keuze voor een bepaalde reactie zelf weer het werschuivend patroon van wie, wat, hoe ziet enzovoort beïnloedt. Elke laars zit immers zoals hij geregen wordt.

Management educatie, die zich baseert op een proces epistomologie zal het belang benadrukken van experimenteel handelen om zodoende op een creatieve manier te komen tot een nieuw begrijpen. Door volledig vast te houden aan een ervaring haalt men er zoveel uit als maar kan. Dat kan pas ais men weerkerend bereid is om met de eigen opvatting in de dinch te gaan, zonder daarin een ander beeld te zien dan slechts één reflectie (5tacey, 1996, 381).

Er maet ook meer begrip worden gekweekt voor de sociale processen van organisaties, en in het bijzonder voor de rol van het eigen gedrag bij de productie en reproductie van organisationeel leven. Minstens zo belangrijk is het om het wermogen bevorderen om te twijfelen aan de 'warheid' van percepties. Waarheid wordt inmers niet ontdekt, maar gemaakt. De dingen hoeven niet te zijn hoe ze er - op het eerste gezicht - vitzien.

Belangrijk is te erkennen dat de managementpraktijk vooral sociaalrelationeel en politiek van aard is. Managers maeten juist leren omgaan met onzekerheid, met twijfel en met mysteries (Chia \& Morgan, 1996).

Dé rol van management educatie is daamee veel omvattender en gaat dus ook over het leren accepteren van de dilemma's van alledag (zowel moreel als instrumenteel), en niet langer te menen dat een 'technische benadering neutrail kan zijn (Roberts, 1996).

Op dit moment is de positie van management educatie overwegend bepaald door een neo-kapitalistisch politiek klimaat, waarin haar gebruikswaarde overigens is toegenomen. Deze ontwikkeling heeft management educatie - ook in universitair verband - geen wimdeieren gelegd. Bedrijfskunde- em managementstudies scoren hoog op beide criteria. Daarbij zij wel bedacht dat dat zolang duurt als dat men meent 
dat er een positief verband is tussen management educatie, de uitkomsten in de managementpraktijk en de individuele prestaties van managers.

Het vermeende succes van management educatie vraggt thans echter om een meer kritische en reflexieve opstelling, die de eigen handelingstheorie tegen het licht houdt, naar alternatieven kijkt en de onderliggende filosofie - ook die tot succes leidt - op zijn houdbaarheid ondervaagt.

Een interessante casus is de dominante rol van rationaliteit in en van organisaties en rationaliteit op en van markten. Moeten niet veel rationeel-lineaire en andere kwantitatieve technieken, doch met name de onderliggende manier van denken, kritisch worden doorgelicht? Dat is een uitnodiging om voortdurend kennis te nemen van kritische studies, maar ook omgekeerd een aansporing opdat het 'kritische' onderzoek steeds begint bij de gevestigde tradities in het managementdenken. Mamagementkennis verdient het goed 'gemanaged' te worden. Het accepteren van verschillen en het koesteren van pluriformiteit is een paradoxale 'must'.

Het bestaan van verschillende mentale modellen en paradigma's over en in organisaties, werpt echter als belangrijkste probleem op hoe hun (potentiële) onverenigbaarheid moet worden aangepakt. De onverenigbaarheid van theoretische systemen is terug te voeren op twee centrale kenmerken van de menselijke rede: allereerst de fundamentele vrijheid van denken om de wereld op een eigen en dus werschillende manier te zien, en ten tweede de ingebouwde claim op universaliteit dat wil zeggen dat men de eigen zienswijze de beste vindt.

Het is in de praktijk vaak niet genoeg om de verschillen tussen alternatieve perspectieven te minimaliseren. Dat kan leiden tot een soort van pluralistische onverschilligheid. Evenmin is het genoeg om hun onderlinge strijdigheid met geweld op te lossen. Dat leidt tot dogmatisme. Voor management educatie wordt het managen van verschillen daarom een queeste naar welk leidend beginsel behulpzaam is om het schip van de organisatie én haar managers te laveren langs de rotsen van totalitaire regels en tussen en door de kliffen van onverschilligheid.

Als management educatie pluriformiteit serieus neemt draagt het zéer veel bij aan innovatie en leren. Zou management educatie daarentegen greep willen krijgen op en precies willen aangeven wat in organi- 
saties door de medewerkers wordt gedacht en gedaan (.. aanpassen of opdonderen!) dan zou haar toekomstige rol zowel moreel als praktisch tegen het absurde aanzitten, en alsnog een soort van 'big brother' creéren.

De keuze voor het leren managen van pluriformiteit ligt voor de hand. Gelet op het tempo van veranderingen en innowaties in de wereld. economie en het bedrijfsleven, draagt management educatie - vanuit die zienswijze - belangrijk bij aan strategische bedrijfsdoelstellingen wan organisatonische flexibiliteit, aanpassingsvermogen en creativiteit, warmee allicht concurrentie voordeel wordt veiliggesteld.

In de microcosmos vinden we een illustratief voorbeeld over hoe aldaar intelligentie (rationaliteit \& lineariteit) het aflegt tegen gedachtentoos rondfladderen (variabiliteit \& processen). Zo leren we nog eens wat:

Als je in een fles een haf doziln bijen en een even groot a antal vilegen stopt en je legt defles horizontaal met de bodem nacr het raam, danzul fe ontdekken dat de bijen zullen bijven proberen een gat doomeen het glas te vinden, tot ze sterven van ulputting of honges terwijl de whegen, in minder dan twee minuten, allemoal weggevlogen zijn door de hals van de fles aan de andere kant.

De eersten (de bijen) zin zo verzat op het licht, dat hun intellgentie hen in dit experiment doet falen. ZII gaan er als vanzelfsprekend vanuit aat de weg naar buiten daar is waar het icht het meest helder is en daar handelen ze consequent naar.

Terwijl nu ner de vederidhte hersens von de bien, zonder zorgen om logi ca of om het mysterie van glas, zonder ook maar te letten op de roep von het licht, heen en weer Jodderen, om ginds tegen het geluk aan te lopen dat valk met de dommen is, en dus noodzakeljkerwils uitkornen bij de wriendelike opening, die hen hun wijheld teruggeeft laldus Maeterinck (n) 141968,89$)$. 


\section{Verboden kennis, verboden fruit}

Er is behoorlijk wat kennis via onderzoek beschikbaar dat inzicht geeft in en reflecteert op de vaak moeizame praktijk van management en organisatie. Toch vind je die niet vaak terug in de curricula. Vooral in de eerste jaren van bedrijfskundige opleidingen treft men overwegend literatuur aan met modernistische en rationeel-lineaire benaderingen wan controle en beheersing. Komt dat omdat die "modeme" idealen nog steeds niet zijn gerealiseerd of omdat reflectie op de praktijk niet de moeite van het uitdragen waard wordt gevonden?

Is het mogelijk en wenselijk om praktijk, theorie, onderzoek, woorketren voor rationele theorie en institutionele beperkingen met elkaar in overeenstemming te brengen respectievelijk op elkaar af te stemmen binmen een opleiding, die moet leiden tot wijsheid, hoop, vaardigheden en realistische vooruitzichten?

Wat doen we met de kennis die we hebben en de kennis, die we onderwijzen? Onderwijzen we wat we weten of wat we graag willen geloven?

Czarniawska $(2003,355-356)$ heeft de verschillen, zo goed als kan, proberen weer te geven in tweelijsten of kolommen. Aan de linkerkant worden weergegeven de (positivistische) zekerheden of wenselijkheden en rechts de relativeringen, de uitkomsten van kritisch onderzoek.

Drie korte voorbeelden:

Voorbeld

Links staat: Een organisatie is een doelgerichte eenheid:

Rechts wordt genoemd toe weten we wat we moeten doen voordat we thebben gedaan pas gaandeweg wordt dudelik wat voar ain we eraongeven?"

voorbeelda

Links staat: "Doeleinden moeten warden vertagld in helaere ohjectieven, wier vervalling beoordeeld moet worden tegen wooraf bepaalde criterla" Rechts is te lezen. "Criteria antstaan alijd gedurende het evaluatleproces" Voorbeeld 3 .

Links staat t deologische controle kant alleen voor in politieke organlsaties economische organisaties dialen op basis van economische controles:

Rechts kan men lezen. Ideologische controle dringt door in alle orga. nisatles en wordt door modes bepaald" (Carnia wska, 2003, 355 356 ). 
Er zijn natuurlijk manieren van onderwijzen, die beide combineren en waarbij de rechterkolom wordt gepresenteerd als tijdelijk voorkomende afwijkingen van de ideale linkerkolom. Onmiddellijk na hun afstuderen kumen studenten immers aan de slag om te proberen wat links staat alsnog te realiseren. Deze manier van onderwijs geven is nogall populair, maar de vrag is of het wel zo goed is erin te blifven geloven?

Waaraan ligt " $t$ dat er twee variaties van organisatietheorieen circuleren en in het onderwijs het meest de voorkeur wordt gegeven alan de linker kolom? Niet erg aannemelijk is te menen dat links het woorkomen' of de 'buitenkant" is en rechts de "werkellikheid zoals hij is." Beide zijn werkelijkheid, of althans twee elementen van dezelfde werkelijkheid, en beide zijn verschijningsvormen die door verschillende mensen verschillend worden wargenomen. of zouden er meer mensen zijn die de werkelijkheid kenmen zoals in de linkerkolom beschreven wordt dan mensen die 'rechts' tegen komen?

Volgt links die logica van de theorie, terwijl rechts probeert de logica van de praktijk te beschrijven? De eerste is makkelijk te onderwijzen, de tweede op de universiteit veel minder. Zijn thearieen, die niet gebaseerd zijn op reflectie op de praktijk, maar meer op het verlangen naar een andere praktijk, niet owerwegend fantasieen of ontwerpen in plaats vam voorschrift of recept. Eenmaal toegepast in de praktijk kunnen ze wel of niet werken. Vooraf valt daar weinig op te zeggen.

Links en rechts kumnen ook gezien worden als voorbeelden wan res. pectievelijk "espoused theory" en "theory in use". Nadeel van rechtts is dat het zelden leidt tot vereenvoudigde modellen. De aantrekkelijkheid van links is mede die 'eenvoud', maar ook en vooral haar esthetische aantrekkeligkheid. De linkerkolom verschaft de illusie van greep op de praktijk te hebben en controle, wat niet geldt voor de rechter.

Het cruciale verschil tussen links en rechts is echter niet het verschil tussen hoop en kennis, noch dat van een orientatie op een betere toekomst en het slaafs volgen van traclitie, maar tussen waarop men hoopt en wat er gebeurt (Czamiawska, 2003, 357-361).

Zou niet Machiavelli's oplossing voor wat het meest effectief is te onderwijzen zijn om de linker en rechter kolom vooral samen te nemen?

Wat moeten we dus onze studenten leren: hoe organisaties zouden moeten zijn/zouden kunnen uitzien in de toekomst of hoe ze heden ten dage blijken te zijn? Czarniawska (2003. 36.2) beschrijft en suggereert 
dat daarop drie mogelijke antwoorden of standpunten zijn te geven.

Modernistisch: Het gesprek moet gaan over de inhoud van de linkerkolom, waarbij voorbeelden uit de rechterkolom worden gebruikt voor een negatief contrast. Het onderwijs moet "progressief" zijn, te lang stil staan bif de inhoud van de rechterkolom is conservatief.

Postmodernistisch: De desillusie met het modernisme leidt tot een omkering van waarden. Reflecteren op de bestaande praktijk wordt "radicalal'; het propageren van modernistische idealen wordt "traditioneel: Reflectie kan leiden tot vertwijfeling (kijk eens naar waar al dat moderne toe heeft geleid) of tot eer (zie hier Utopia, waar al die moderne dromen werden afgewezen).

'Past'modernistisch: in overgangstijden, in tijden van grote verandering worden de oude idealen al afgewezen nog voor nieuwe idealen zijn aangenomen. In dat soort tijden, krijgt reflectie op de hedendaagse praktijk een centrale plaats in de discussie, als een soort "stopwerf" tussen beide idealen. Voor de toekomstige idealen, vallen dan twee denkrichtingen op: na de chaos kan een soort van nieuwe theacratie komen, of een nieuwe toestand met vele idealen.

Mensen die vervolgens mopperen over onze onbruikbare kennis en dat we geen grip krijgen op de 'echte' wereld zijn vaak praktijkmensen met gewestigde belangen die willen dat wij hun echte wereld ook onze echte wereld maken. Dat komt natuurlijk omdat mensen uit de praktijk valk ook niet goed weten, evenmin als wij, waar hun echte wereld uit bestaat. Hum echte wereld is een gekke mengeling van het ideaal van rationele theorie en het zich gedragen naar wat wan dat ideaal over is, in hun voortgaand streven zich als serieuze speller te presenteren. Maar de praktilk en de van-dag-tot-dag logica, die deze idealen en representaties ondersteunen en er mogelijk door zijn, worden al snel verwaarloosd door academici, terwijl 't werboden kennis woorstelt woor de praktijkmensen zelf, woorzover ze dat niet uitkomt (Weick, 2003. 38i).

In de thuidige tijd van grote veranderingen, blikt het verbodene nu net die praktijken te zijn, die mensen in staat stellen een raamwerk op te stellen om de transitie beter te begrijpen. Dat is de les die praktijkmensen en theoretici elkaar kunnen leren, en een les die beiden ook aan studenten kummen doceren.

Uit het verre Australie kwam een interessante reactie op dit debat over bedrijfskunde en management onderwijs. Temeer daar stewart 
Clegg een dezer dagen hier aan de Faculteit der Economische Wetenschappen en Bedriffsunde komt werken is het goed nu al te weten hoe hij over een en ander denkt.

De rechter kolom van Czarnawska die door haar "Forbidden Knowledge (verboden kennis) wordt genoemd likt wel wat op het verboden fruit, waar onze mythische voorvader Adam niet vanaf kon blijven. Het verlangen was zo groot en hoe makkelijk zijn we niet te verleiden? We weten inmiddels wartoe het toegeven aan dat specifieke verlangen heeft geleid, tot de zondeval!

De linker kolom is dan die van de zekerheden, van controle, wan vertrouwen. Die voorkomt dat we toegeven, dat we postmodern of zelfs voorbij postmodern oftewel 'pastimodern willen zijn.

is de linkerkolom niet net eer mantra, een credo, een soort van catechismus, als we die maar vaak genoeg herhalen bilfft het kwaad vanzelf weg? Waarbij het kwaad natuurlijk is dat de organizationele wereld even vreemd en moof en lelijk is als de wereid van relaties, van problemen, en even ondoorgrondelijk en even moeilijk als al die andere terreinen: van families, van vrijers, kinderen en vrienden, met al dat gekibbel, uiteengaan, opbreken en weer samenkomen, al dat gerommel warmee we onze levens weer aan elkaar naaien. Misschien als we die mantra maar vaak herhalen, gaan we nog geloven in het onwaarschijnijike, geloven in eem schone wereld vari organisaties zonder angst, zonder onrust, zonder pijn, zonder problemen. Misschien redt de mantra ons nog van de gekte vam ook maar gewoontjes te zijn (Clegg, 2003, 376).

Mantra's hebben in elk geval een doel: concentreer je je er lang genoeg op, dan kan je alledag zo eruit werken. Bovendien, wie wil studenten nou bang maken? is het niet veel beter ze een hart onder de riem te steken? Vooral nu ze terugkeren naar de umiversiteit (of er voor het eerst komen, naar die vreemde en verveemde wereld van theorie en onderzoek. Maar wat als ze eenmaal daar, vervolgens ontdekken dat de bedrijven, organisaties en carrières, waarvoor ze grag een toegangsticket willen verdienen geen bouwsels van rede en rationaliteit zijn, zoals de tekstboeken beloofden, wat dan?

Studenten houden valy antwoorden, hoe vaak is ons dat niet gezegd als de reden warom dat on zo verschrilkkelijk vervelende, grote, saaie boek de verplichte eerstejaars cursustekst is. Het geeft antwoorden, 't is 
een bruikbare kaart, het brengt je nergens waar je zou kunnen verdwalen, alles is ingedeeld en ingekleurd en ook nog eens geillustreerd.

En wat krijg je meestal uit de rechterkolom? Juist ja, kopieën van tijdschriftartikelen, met alleen maar moeilijke woorden. Ongemakkelijke verhalen en pessimisme, geen heldere, mooie, zonnige dagen leestek.. sten, die beschermen tegen de slechte, rotte wereld buiten.

De linker kolom maakt wan de wereld één geheel; het bewerkt de wereld in ontcijferbare, verteerbare en vooral handige pakketjes (Clegg. 2003.377). Was dat nou niet net de reden voor ons om op de universiteit ons MBA te gaam halen?

Maar waarom zouden we links niet ook kunnen zien als een manier om je chic en deftig, intellectueel aan te kleden, voordat je naar buiten de wereld ingaat. Gekleed voor het succes en het serieuze werk. Net zoals we ons graag en bij gelegenheid kleden woor het theater, een concert of een oratie? 


\section{Strategisch Leiderschap is geen verboden fruit}

Moeten we hedentendage nog opteren voor management educatie in de gangbare betckenis of zouden we het niet veeleer moeten hebben over leiderschapsontwikkeling, over het opsporen en ontwikkelen van (het) uitzonderlijke (in) mensen, in stat om bedrijven en organisaties te leiden in de zre eeuw, zo stat in de omschrijving van de leerstoel.

Naast het ontwikkelen van toekomstige leiders is minstens zo belangrijk het opzetten van nieuwe processen en samenhangen in bedrijuen, wil men beter in staat zijn om met succes te concurreren in de dynamische, snel veranderende economie. Het een kan niet zonder het ander Reden watrom die twee tezamen nogal eens gelabeld worden als "strategic leadership development". Op de meeste business schools wordt hieronder een combinatie verstaan van gangbare "executive edu. catron" activiteiten met management, leiderschaps en organisatie-ontwikkelings technieken. Als het aan de bedrijven ligt wil men het liefst praktische "real time" leerlaboratoria binnen hun organisatie scheppen on continu "on the job" te leren, kennis door te ontwikkelen om daarmee als bedrijf maximaal concurrerend te kunnen zijn.

Leiderschaps programma's zijn jarenlang alleen maar 'gedraaid' voor een kleine elite. Prestigieuze business schools kennen al jaren evenzo prestigieuze "Advanced Leadership" programma's, waarvoor top-executives in de rij stalan. Dat is nog steeds zo, maar ondertussen hebben vele bedrijven de noodzaak onderkend om via strategische leiderschapsontwikkeling zowel te werken aan de richting waarin het bedriff zich will of moet ontwikkelen als aan de verdere ontwikkeling van de eigen medewerkers. Universiteiten en businessschools, die dachten het monopolie te hebben op het meer exclusieve ontwikkelingsmodel van leiderschap. moeten toezien hoe andere spelers inmiddels ook in het oog springende leiderschapsprogramma's op de markt brengen. Ook zij moeten nu concurreren om zich staande te houden onder deze veranderingen.

Het is zaak, gelet op het speerpuntkarakter als de breedte ervan, om als nieuwe. Mastrichtse buisiness school alert in te spelen op de relevante trends rond strategisch leiderschap. Vandaag de dag zijn bedrijuen met name geinteresseerd in leiderschapsontwikkeling gekoppeld aan evaring en aan de concrete werkomgeving. Vooral het "action learning" 
model, dat natw aansluit bij het alhier gepraktizeerde concept van probleem georienteerd leren biedt een krachtig raamwerk om in leiderschapsontwikkeling te investeren en te letten op het rendement ervan.

Bedrijuen prefereren leiderschapsontwikkelings programma's die op maat zijn gesneden en dus beter aansluiten op de verandeirende markten. Ze zijn veel minder geinteresseerd in de gangbare open program. ma's. Dat will echter ook weer niet zeggen dat ze precies weten wat voor soort ervaring en leren ze nodig hebben. Er is bij velen twijfell of ze zelf wel in staat zijn zulke ervaringen te ontwikkelen en intern effectief te maken. Daarom wil men toenemend advies over wie goede programma's voor strategisch leiderschapsontwikkeling kan leveren en wat dat betekent.

Er ontstaan dus allerlei kansen voor aanbieders van zowel inhoudelijke expertise als proces expertise voor het bedrijfsleven. We praten dan over "partnering" of samenwerking. Samenwerking met bedrijven on oplossingen voor proces en inhoud te vinden, en samenwerking met andere aanbieders om op tijd en in de juiste omvang programma's en/of workshops te leveren. Business schools die in staat zijn orn innovatief samen te werken met bedrijwen zijn daarbij in het voordeel.

Universitaire business schools kunnen ook met onderzoek belangrijk bijdragen aan het exploreren en adresseren van toekomstig strategisch leiderschap. Daar is duidelijke vraag naar, zoals blijkt uit de groei van gecombineerde bedrijfs- en universitaire onderzoekscentra. Overigens hebben met name consultants zich met succes op het terrein van strategische leiderschapsontwikkelingen geworpen, vaak ten koste van de traditionele kennisontwikkelingsrol van universiteiten. Bedrijven zoeken nieuwe ontwikkelingstechnieken en 'partners' om in te spelen op de noodzaak van verandering en herstructurering. Ze zijn daarbij sterk gericht op high-potentials. Tegelijkertijd is het voor bedrijven belangrijk dat leiderschaps ontwikkeling goed aansluit bij het gebruik van zulke HRM-instrumenten als selectie, beoordeling, beloning enz. met name in meer horizontale en flexibele omgevingen met veel zelfstandige professionals

Al deze ontwikkelingen vinden plaats in een context waarin de vraag naar strategische leiderschapsontwikkeling alleen maar groeit, zij het niet via traditionele 'executive' programma's, maar door actiegerichte processen, gebaseerd op toegepast onderzoek. Samenwerking is essentieel en het slagen ervan wordt afgemeten aan wat zulke activiteiten bijdragen aan het succes van de bedrijven en van de individuele deelne- 
mers. De opgave is om een productieve fit te vinden tussen wat men wil met strategisch leiderschap en hoe een organisatie het beste leert.

Zover het ambitieuze idee achter de leerstoel. In het echt gat dat natuurlijk in kleine stapjes, maar wel wooruit. Management educatie oftewel strategisch leiderschapsontwikkeling is een bijzonder interessant en serieus spel. Men kan lijnen uizzetten, spelregels opstellen, maiar hoe gaat het daadwerkelijk gespeeld worden en blijven de regels en de Ifinen wel of niet buiten discussie? Hoe kan men geschikt inspelen op de begeerte van anderen om hen te leiden, weg wan het nu, naar waar men gaandeweg, anders naar is gaan vitzien. Ik ken geen betere manier om de feitelijke magie van verlangen en verleiden te beschrijven die zich vrijwel steeds voltrekt aan al die professionals, die nast een drukke baan, besloten hebben zich alsnog verder te bekwamen en te verdiepen als manager. Het proces en de inhoud waarlangs dat gebeurt raken zo met elkaar vervlochten, dat het hoe en waarmaar men op weg is telkens van plaats verwisselen, geleidelijk elkanders rol overnemen om gezamenlijk te leiden naar wat van geen afzonder lijk noch aanvankelijk werd gedacht. 


\section{Is "postgraduate' management onderwijs aan- trekkelijk?}

Het weelgebruikte woord onderwijs informeent in deze context niet wolledig. Het is incompleet, omdat uiteraard ook leren ertoe behoort. Daarom is educatie valk een betere term. Idealiter gaat het bij management educatie om de overdracht van lets van waarde, iets walaran men zich committeert. Men moet wat waardevols hebben geleerd. Als tweede moet educatie gaan om vermeerdering van kennis en inzicht, met een voldoende kennisperspectief. Het draait dus niet zomaar om informatie of feiten op zich. Het gaat ook om een conceptueel schema, waarwan men de principes begrijpt en kan verklaren. Het kennisperspectief geeft aan dat men de verworven, specifieke of gespecialiseerde kennis in een breder kader kan plaatsen. Feitenkennis is anders niet meer dan een etiket op een lege fles.

In elk geval betekenen educatie en leren altijd dat de lerende verandert, en niet louter alleen in gedrag. Bij alleen dat laatste is sprake van training, wat overigens ook belangrijk is. 'Last but not least' kan het bij educatie voor de lerende alleen maar gaan om de bereidheid te leren vanuit volledige vrijheid van denken en handelen. Leren is immers niet werplicht, net zo min als, carrière maken.

Het mag duidelijk zijn dat management educatie aspecten van zowel beroepstraining als van educatie zal omvatten, bij voorkeur van de zogenoemde "liberal education". Een zichzelf serieus nemend programma van management educatie stelt de vaardigheid van deelnemers om intellectueel te kummen analyseren en sociaal competent te zijn (denk aan emotionele intelligentie) graag voorop. Daarnaast gaat het om (inter)persoonlijke vaardigheden als beslissen-onder-onzekerheid, met begrotingen kumnen omgaan, ondernemerschap e.d. Het helpt zeer als men al kennis van organisaties heeft, en met name weet hoe ze te analyseren.

Het feit op zich dat wele instituties zeggen zich te richten op educatie is niet voldoende bewijs dat dat klopt. Ook als men zichzelf docent noemt, dan is wat men doet daarom nog niet onderwijs of doceren. De dubbele bodern wan op deze manier definiëren wat onderwijs is, speett ook zodra we management willen definiëren met te verwijzen naar wat managers doen. Zonder extern criterium is het moelijk te bepalen of wie zich manager noemt dat ook daadwerkelijk is. Dat maakt een discussie als we het over management educatie hebben nlet per se mak- 
kelik, maar wel boeiend. Het feit dat aan die termen een positieve betekenis kleeft, maakt het verleidelijk hen, ook voor verkeerde doeleinden te gebruiken. Sommige leerstukken die voor 'educatie' doorgan zijn in hun werking soms beter aan te duden als: indoctrinatie, manipulatie, propaganda enzovoort (Czegledi, 1996, 329).

In elk beroepsgericht opleidingsprogramma gaan de deelnemers er redelijkerwijs vanuit dat hum prestaties er beter van worden. Management educatie spiegelt zich aan wat elders bij opleidingen tot gevestigde beroepen gebeurt, met een aanbod van kennis en vardigheden op meerdere funktionele gebieden. Risico daarbij is de mogelijke invloed van gevestigde belangen. De bestaande disciplinair of funktioneel inhoudelifke verhoudingen blokkeren soms onderzoek en dan weer onderwijs of training orndat zo'n aanpak miet past in de funktionele invulling van hun ramwerk.

Uiteraard kan geen enkel managenent opleidingsprogramma ervaring volledig vervangen. Well kan men helpen de competentie te verwerven om meer te halen uit de eigen ervaring en die van anderen. Dat is temeer zo als men zich realiseert dat ervaring niet is wat met je gebeurt, maar wat je doet met wat je overkamt. Daarbij helpt het eerdergenoemde kennisperspectief en het ontwikkelen van een kritisch en refiexief vermogen. Open en objectiverende discussies dragen daar aan bij.

Fen tweede link tussen educatie en de prestaties van managers ligt in een verbeterd vermogen om met verandering om te gaan. Als men voor veranderingen alleen afhankelijk is van het managen van cultuur dan gaat dat vaak langzaam. Educatie en onderwijs zijn dan effectiever. Een goed opgeleid manager zal minder snel schrikken van het nieuwe en worden gestimuleerd om verandering als iets blijvends te begrijpen.

Als blijvende beperking, maar ook als aansporing. geldt voor management educatie, hoe bijzonder het ook is, dat alle nieuw verworven kennis over hat verleden gaat, terwijl elke door een manager te nemen beslissing op de toekomst slat.

De productie van managementkennis was tot voor enkele tientallen jaren wolledig in handen van thet bedrijfsteven. Sinds eind jaren viftig zijn in Europa - in de verenigde Staten was dat al weel langer het geval ook de universiteiten c.q. universitair georienteerde business schools relevante managementkennis gaan ontwikkelen (Locke, 1989). Het distribueren ervan was echter in Nederland gedurende lange tijd 'een 
parade van gemiste kansen' (van Baalen, 1995; 295 ).

Kennis en kennisproductie die altijd al leken te zijn geinstitutional seerd in (hoge)scholen en universiteiten zijn steeds meer los daarvan geraakt. Nu en in de toekomst zal men kennis willen gebruiken waar ze is en niet waar ze traditioneel is georganiseerd. "With knowledge footloose, knowledge business will become a common phenomenon" (Hague, 1996. 22). De werhoudingen in de waardeketen zijn de laatste jaren redelijk op hun kop gezet. Twee factoren dragen daar belangrijk aan bij: de toenemende kennisintensiteit van de economie en de ontwikkelingen in de informatie- en communicatietechnologie. 


\section{Wat kun je bij management educatie ver- wachten?}

Er zijn de laatste wintig ja ar nogal wat 'gebreken' in de management curricula gesignaleerd (Porter \& Mckibbin, 1988 en het MACIS project. 1999): te weing integratie, veel ellanden met kennis en te weinig brug. gen; te weel onderwijs-en te weinig leergeorienteerd, met te weinig discursie; de 'zachte' vaardigheden voor managers blijven onderbelicht; te weinig contact tussen functionele departementen, met als gevolg onnodige owerlappingen; theorieen, oefeningen en cases sluiten vaak onvoldoende aan bij de bedriffspraktijk en toekomstige ontwikkelingen: te veel eenrichtingsverkeer, en te weinig gebruik van ICT.

Daar komt nog eens bij dat men vanuit de praktijk constateerde dat de houding op de faculteiten en business schools duidde op genoeg aan zichzelf te hebben, op zelfvoldaanheid, met nauwelijks aandacht voor stirategische initiatieven.

Inmiddels is er behoorlijk wat veranderd, in elk geval wordt door ieder aan de gebreken gesleuteld. In plaats van onderwijzen staat leren nu voorop. In Maastricht was dat overigens al langer zo, niet in het minst omdat leren (het zelf lerem aan de hand wan praktijkcases) het hart vormt van het typische probleem georienteerde leerconcept. Er is ook een duidelijke verschuiving van individueel naar groepsgewijs leren in kleine teams. Ook hierin was Maastricht al vroeg. In het kader van MBA programma's is ook niet onbelangrijk dat de cohort benadering, of wat vroeger heette het expeditiemodel vooropstaat.

Integratie krijgt ondermeer vorm in praktijk projecten. Helaas will het met het integreren vam cursussen nog slechts op weinig plaatsen vlotten. Wel wordt inmiddels op vaardigheden veel meer getraind dan voorheen. ook de intellectuele vindingrijkheid en reflexiviteit wordt op verschillende manieren meer aandacht gegeven. Leren betekent inmiddels "lifelong learning of tenminste een carriere lang investeren in bijtanken. De kennisintensiviteit wan de hedendaagse, industriële en diensten bedrijvigheid wragt om geregeld en bekwa am anticiperen en zo nodig aanpassen.

Het nieuwe onderwijskundige paradigma gaat om leren te faciliteren. Maar hoe ziet zoin nieuwe leeromgeving uit als het gaat om het faciliteren wan leren? Wat betekent dat voor 'docenten' in zo'n andere rol?

Er zijn nogal wat verschillendie manieren wan leren. De leercyclus van Kolb laat dat mooi en duidelijk zien. Die cyclus illustreert bij uitstek waarom 
en hoe het gaat bij management educatie voor mensen uit de praktijk. Niet woor niets heet het de experientiele of enarings leercyclus: het gaat om reflexieve observatie, concrete ervaringen, actief uitprobeien en abstract of theoretisch conceptualiseren. Alhoewel alle vier door Kolb onderscheiden vormen door vrijwel iedere 'executive' lerende worden gepraktiseerd, gebeurt dat voor elk verschillend en in variërende gradaties (de Galan, 2003. 53-91). Kolb's model combineert de behoefte aan theoretische kennis met de noodzaak van praktische toepassing. De traditionele opvatting als zou kennis zo maar uit de praktijk te tillen zijn, onderwezen aan studenten en weer zijn in te passen in de praktijk, staat dus ter discussie. Voor veel mana. gement faculteiten en business schools is die aanpak lang een bedrieglijke voorkeur geweest (van Baalen \& Moratis, 2001,83).

inmiddels wordt management als een eigen gebied wan kennis al lang niet meer gezien als een enkelwoudig, stabiel concept van kijken naar of omgaan met zaker. Evenmin valt het nog te karaktiseren als éen enkel, beschikbaar paradigma. In het management denken zijn er vandaag de dag simultaan, meervoudige en concurrerende paradigma's. Die windt men ook terug in vele MBA en Executive programma's als de essentie van het leermodel van wisselende perspectieven: "re-framing". Het leren opzetten van andere brillen bevordert het vermogen om zaken, situaties of mensen op een andere manier te zien; om ze onder een verschillend perspectief en belang te beoordelen (van Baalen \& Moratis, 2001.68).

Sinds de jaren negentig zijn er werschillende leervomen en navenan. te leercentra gevormd, varierend wan 'leren te leren en af te leren' tot 'kwaliteit als cen kernwaarde'. Zle hieronder:

learning to learn and whearn

- Partherships with clients

- Manogers as learning focillators

- Comprehensive portfolio of learning resources

- Professional diagnosis and counseling

- Focus for networking and benchmarking

- Multiculural global aulook to Groaden vislons

- Wide use of educational technologyfvirtual mindsel

- Relationship marketing and dient management

- Collaborative relationships between providers

- Encouragement of lifelong leaming

- Qually as a core of value 
Nog meer andere manieren van leven houden in het van dag-tot-dag probleem oplossen, ervarings gebaseerd leren, in het-werk leren, "action learning, leren door reflectie, leren van 'peer' gedrag, experimenteel leren, leren via discussie en debat.

Al deze benaderingen zijn erop gericht programma's en activitaiten te ontwikkelen, die berusten op heldere en doordachte leetbeginselen, waarbij kennis gezien wordt als divers naar inhoud, vorm en verspreiding. War het dan omgaat is om een discussie of discours te faciliteren tussen verschillende vormen en eigenaren van kennis, waaronder praktijkmensen en 'reflectoren'. De benadering van management educatie is er dan een, waarbij zoveel als kan wordt voortgebouwd op expertise over het leerproces, expertise over management problemen en disciplines, lettend op de verspreidde, meervoudige, maar ook onzekere aard van management kennis (Burgoyne, 1994, 40). 


\section{En de bedrijven dan met hun 'corporate uni- versities'?}

Universiteiten en business schools hebben aanvankelijk de vraag naar en de uitdaging van in-company onderwijs en training en thet opkomen van 'corporate universities' over het hoofd gezien en vervolgens genegeerd.

In-company educatie is de snelst groelende sector en is veel meer dan louter trainingen. In het gebruik van leertechnologieen is het incompany onderwijs revolutionairder dan het meeste onderwijs van universiteiten. In-company onderwijs is de voorbode van veranderingen in andere opleidingssectoren.

Vandaag de dag zijn het multi-media onderwijs en training op basis van ICT belangrijke componenten geworden van educatiesystemen. zoals die door bedrijven worden opgezet. Een goede instructeur met tien intelligente PC's wint het gemakkelijk van tien gemiddelde docenten al nemen die nog zoveel leerboeken mee. Bedrijven zijn zonder dat na te streven toenemend concurrerend voor het onderwijsestablishment (Davis, 1995, 67). Door het gebruik van interactieve multimedia verandert het leerproces definitief van meer passief naar meer actief De controle en het toezicht verschuiven naar de individuele gebruiker zelf, de lerende. Daar hoort die verantwoordelijktheid ook te liggen, dat motiveert en stimuleert. Omdiat we elk verschillend leren, de een meer audithef (luisteren) en een ander meer visueel (kijken) is ingesteld en weer een ander bij voorkeur analytisch (lezen) of kinestetisch (doen) nieuw kennis opdoet, kan daarop makkelijker worden ingespeeld. Als men zelf werantwoordelijk is voor wat men leert, kan en hoeft men zichzelf niet meer te verbergen of na te blijven. ICT is bovendien veel geduldiger (Davis, 1995, 77).

De groei van in-company onderwijs en training is exponentieel in vergelijking met de groei van academisch onderwijs. De half-waarde tijd van kennis en ervaring is veel korter dan voorheen. Daarom is een gang. bare opvatting binnen opleidingsgerichte bedrijwen dat sineller en beter leren uiteindelijk het belangrijkste concurrentie voordeel oplevert. Hoe sneller bedrijuen moeten veranderen, hoe meer het nodig is te investeren in leren. Hoe korter de halfwaarde tijd van kennis, hoe sterker de band moet zijn tussen educatie en ondernemen. 
Nochtans zullen bediriven, inclusief hun elgen carporate academy of 'corporate university' als woorheen traditionele universiteiten nodig hebben vaor 'fundamenteel' onderwijs en onderzoek. Het formele onderwijs dat platsheeft bij bijvoorbeeld Arthur Andersen en Motorola is in een alatal opzichten wolledig vergelijkbaar met dat van top academische instituten. Uiteraard is niet alle opleiding en training bij bedrijven wan zulk niveau. Vele 'corporate universities' zijn omgedoopte trainings en 'management development'-centra. Maar, het is indicatief dat ze zich bewust met thet label universiteit tooien. De ambitie is duidelijk leren is bellangrijk en men verwacht er veel van. Paradoxaal is dat met de erkenning van opleiding en training zeer vele bedrijen aangeven hun mensen als een 'kapitaa goed' te zien, terwijl evenzovele andere bedrijw. wen hun meinsen nog steeds als louter een kostenpost zien.

Nogal wat traditionele academici hebben moeite met de naam "corporate universities. Ze winden dat de idee van de universiteit ermee tekort wordt gedaan, omdat ze geen academische diepte of breedte hebben. Weinig 'corporate universities' hebben aandacht woor filosofie, noch lijken ze te streven naar hogere waarden. Men vergeet dan dat dat ook niet geldt voor veel reguliere universiteiten. Universiteiten lijken soms weel op dinosaurussen. Inmiddels wordt steeds duidelijker dat alterinatieve kennisbedrijuen de markt al lang veroverd hebben, nu uniwersiteiten zich beginnen te realiseren hoe vitaal het is erin te participeren. Zulke bedrijwen kunnen als 'virtuele universiteiten' bijna alles leveren en ze weten deskundigheid en expertise overal wandaan te halen. De wragg is of de meeste universiteiten bereid zijn te veranderen om een vooraanstaande maatschappelijk kennismakelaar te blijven.

Levenslang leren schept nieuwe marktsegmenten en wergroot het domein wan wie door wie, waartoe wordt opgeleid. in-company onderwijs groeit en wordt beter door de bedrijven dan door universiteiten bediend. Velen van ons zitten vast in een oud paradigma. Dat geldt ook voor wele business schools. Uit Amerikaans onderzoek blijkt dat business schools aldarar nauwelijks een kwart van de snel groeiende millarden. mark van management educatie voor hun rekening nemen. Dat is in Europa niet veel beter.

Alhoewel er vele alanzetten zijn om ICT meer op te nemen in het universitaire onderwijs is dat op zich niet woldoende. Het gaat overigens niet om het veranderen van de manier waarop men leert. Leren op zich 
is in de loop der eeuwen niet veel veranderd. Het gat erom dat ICT leren meer faciliteert dan dat vaste patronen en gevestigde instanties doen. Ook de verantwoordelijkheid komt anders te liggen en verschuift ten gunste van de lerende. Het is de combinatie van die twee: een grotere wrijheid en meer verantwoordelijkheid wat leren met ICT zo aantrekkelijk en succesvol maakt (Tai, 1977).

ELEUM (Electronic Learning Environment Universiteit Maastricht) aan de Faculteit der Economische Wetenschappen en Bedriffskunde is een prachtige illustratie voor de mogelijkheden die een geavanceerde ICT infrastructuur bieden. Het feitelijk gebruik heeft echter tijd nodig om zich te ontwikkelen, niet in het minst omdat er ook marktprincipes onder liggen van a anbod en vraag, zo blijkt. Tezelfdertijd zijn we ons er in de business school zeer wel van bewust dat de beste kennistransfer niet noodzakelijk is gebaseerd op ICT, maar vooral slaagt door de interactie tussen mensen.

Idealiter zouden business schools en bedrijven nauw moeten samenwerken in het ontwikkelen en opzetten wan een samenhangend concept van virtuele educatie, kennismanagement en leiderschaps vaardighe. den. Hoe meer dat management educatie en leiderschaps training verbonden wordt met de kennisbasis en het management en de professionals van bedrijven, des te meer toegevoegde waarde zal ontstaan voor bedrijwen én voor business schools. Het ontwerpen en opzetten van cursussen en traïningen moet op een moderne, ICT gestructureerde manier inhaken op de kennis- en competenties netwerken van bedrijven (Baets \& van der Linden, 2000,68).

Het gaat dan in feite om een bedrijfs leerstrategie, die zowel aansluit bij de idee van corporate universities als bij de curricula en leer methodologie van business schools. Het hybride business school model is daarvan een uitwerking. Kenmerkend is de nadruk op leven landers dan op instructie), continu of carrière lang, verschillende management paradigma's, op competenties en vaardigheden, leer gemeenschappen, inte. grerende werk-leer projecten, samen met en op basis van een geavänceerde technologische infrastructuur. Veel van wat we hedentendage kennen als 'online education wordt nog een stuk verder gebracht. Men zou kunnen zeggen dat 'e-learming' zalets als 'we-learning' wordt door de toepassing van op groepen gebaseerde redeneer- en overlegsystemen en gekoppelde neurale netwerken. 
Wat betekent het voorgande voor de situatie alhier? Wil de unversiteit c.q. de faculteil haar missie zoveal als kan troww blijven, dan zal zij ook de regie van het kennisontwikkelingsproces in haar relevante omgewing stevig in handen moeten willen nemen. Universitaire func. ties en processen zullen bovendien moeten wirtualiseren willen ze niet snel obsoleet raken. De faculteit zat ondermeer via de business school nog meer greep moeten krijgen op en moeten bijdrage aan de voortgaande ontwikkelingen in kennisvergaring en -verspreiding in bedrijven en sectoren.

Voor organisaties als universiteüten kan leren niet de eerste prioriteit hebben als men niet zelf ook een lerende organisatie is, respectievelijk als men levenslang leren niet voorop steit woor wie er werkt. Hoe kan nieuwsgierigheid daarvoor worden opgewekt, hoe krijg je personeel en docenten daarbij betrokken? Idealiter zouden docenten en staf niet getraind hoeven te worden, ze zijn (immers) zelf en bij uitstek lerenden? Als de beloningssystemen leren, exploreren en het experimenteren met de eigen organisatie en met leerprocessen meer zouden erkennen en aanmoedigen, dan zouden ook onderzoek en onderwijs veel meer geintegreerd zijn (Nkomo, 1996, 92). Volgens Boyer spreekt het woor zich dat als een professoral onderzoeker hevig in een speciaall onderwerp is geinteresseerd, dat dan onderwijs en leren over dat onderwerp onderdeel wan zijn/haar onderzoek zal zijn "Boyer, 1990). 


\section{Reflexiviteit op de praktijk? Het komt goed!}

Ervaringsleren is niet én methode, maar meer een kaart wan leergebieden, een referentiekader warbinnen verschillende manieren van leren voorkomen en elkaar beinwloeden. Leren betekent nooit twee keer eenzelfde ervaring hebben. Van fouten kan men meer leren dan van succes. Wat werkt wordt zonder meer geaccepteerd. Pas als iets fout gaat stelt men de wraag naar de verwachting of de veronderstelling erachter: "Good judgment is the result of experience, and experience is the result of bad judgment." (Micklethwait \& Woolridge, 1996.122).

Hoe en wat managers leren omvat nadrukkelijk alle combinaties van formeel en informeel management en leren. Meer nog, in onderzoek naar hoe en wat managers leren is steeds veel aandacht geweest voor thet informele of feitelijke. Het leewwendeel van de bestaande managementexpertise is het resultaat van als zodanig ongeplande management. en leerprocessem. Deze soort van expertise wordt toenemend begrepen als voortkomend uit zogenoemde "commumities of practice". met een situatie-specifiek karakter waar men het meeste leert van informele processen (Fox, 1997, 37).

Deelnemers aan 'executive' programma's, die werkervaring meebrengen zijn geen tabula rasa meer is. Ze hebben nast ervaring, modellen en theorieèn, verwachtingen en zelfs vaak een persoonlijke leertheorie. Het werken met deze ervaringen en abstracties is essentieel om opnieuw leren te begunstigen. Men doet zo recht aan het individu door niet langer 'economies-of-scale' te willen maar 'economies-of-scope', dat wil zeggen dat de leermethode zich richt op de aard en samenstelling van deelnemersgroepen, inclusief op de variatie in leren daarbinnen.

Een goede sociale context bevordert openheid, het voortbouwen op elkaars ideeën en het zo nodig aangaan van conflicten, meningsverschillen en daarvan leren. Management als sociale, politieke en economische activiteit nodigt ook uit om paralellen met het eigen leven te zoeken.

Bij post-initieel en na-ervaringsonderwijs moeten zowel kennis, vaardigheden en waardegevoeligheid ontwikkeld worden. Het is moei lijk om daar een goede verdeling voor a an te geven. Prangend is immers de vraag hoeveel tijd dan wel waraan moet worden besteed. Een mogelijke benadering is om de hoeveelheid st of die wordt behandeld te verminderen en de manier om meer te leren te verhogen. Dat zou wel eens erg bevorderlijk kurnen zijn woor de duurzaamheid van wat we 
leren. Dus minder aandacht voor inhoud, maar meer voor duurzaamheid van wat is geleerd.

Voor een goed begrip wan de praktifk en de reflectie erop is het de moeite waard goed te kijken naar verschillende typen van managementpraktijk, bijvoorbeeld naar de mate waarin managers - in de praktijk - meer of minder theoretiserend bezig zijn. Er vallen dan een drietal typen op.

Het eerste betreft de gangbare, algemeen geaccepteerde en overwegend als effectief beschouwde managementpraktik, waarbij handelen en bij voorkeur het aanstonds actie ondernemen voorop staat.

Type twee zet een stapje terug door bij voorkeur alvorens iets te doen nog eens goed na te denken over eerdere ervaringen en acties. Er is sprake van een meer reflectieve managementpraktijk (Burgoyne \& Reynolds. 1997. 2). Daarmee hangt duidelijk een eigen handelings'theorie' samen. die aangeeft wat er moet gebeuren en waarom het zal werken.

Bif het derde type gat het om meer kritische reflectie, men denkt nóg meer na en vooral dieper. Die extra laag van reflectie op de eigen handelingstheorie, gaat over verschillende 'rivaliserende' verklaringen en a anpakken. Deze tweede manier van denken stelt geregeld kritische vragen aan (en kan leiden tot herziening van) de eigen "theorie". Men leert van eerdere praktijk uitkomsten en ontdekt waarom ze all dan niet spoorden met wat men verwachtte.

Er is een markante overeenkomst met het theoretisch onderscheid in typen van leren als 'single loop', 'double loop' en 'deutero' leven (Argyris \& Schon, 1996).

In de managementpraktijk leidt die kritische reflectie ondermeer tot het beter kunnen inschatten van de instrumentele aspecten van manaw gement. Wat voor acties zijn wanneer en onder welke omstandigheden nodig om de gewenste resultaten te boeken, en welke waarden, dat wil zeggen wat voor ethische en morele aspecten zijn daarbij in het geding? Als men kritisch reflexief in de managementpraktijk staat, is men ook beter in staat om die praktijk en haar omgeving te zien als onderdeel van een veel bredere economische, politieke en sociale context. Men begrijpt dam beter wat voor soort van samenleving het is die mede door het eigen handelen wordt gereproduceerd of veranderd. Wat betekent die houding voor de theorie van management educatie? Hoe kan een kritisch reflexieve houding via management educatie worden beworderd? 
Opvallend is dat de praktijk van management educatie de laatste jaren wolledig langs een theoretisch patroon verloopt. De werwachtingen en het gedrag van 'executive' deelnemers aan open of in-company programma's ondersteunen en reflecteren de theoretische onderscheidingen. Men wil niet alleen van docenten, maar ook van elkaar weten hoe zaken en/of processen zijn, hoe ze zouden moeten of kunnen zijn, waar om het wanneer anders had gekund en wat de invloed is van onderlig. gende opvattingen en waarde oordelen. Op die mamier leveren intensieve, interactieve sessies met managers steed weer een eigen bijdrage aan de ontwikkeling van een kritisch reflectieve mamagementpraktijk.

Wie recentelijk betrokken was bij 'executive" cursussen onderkent hoezeer deze suggesties en aanwijzingen bevatten voor vanuit de praktijk geconstrueerde theorievorming over de opzet en inrichting van management educatie. Denk aan:

Normatieve theorieen die antwoord geven op de vraag: Wat moet er gebeuren? Hoe moeten bijvoorbeeld onderwijs en trainingen worden georganiseerd (qua procedure, voorbeelden, oefeningen en feedback op effectiviteit). Daarachter ligt een, net zo normatieve opvatting over hoe mensen leren.

Beschrijvende theorieen met antwoord op de vraag: Wat gebeurt er normaliter, wat komt regelmatig terug? Welke zijn bijvoorbeeld de verschillende rollen die mensen telkens weer aannemen als ze (moeten) samenwerken in een team.

Interpretatieve theorieen die pretendieren te verklaren warom de dingen gebeuren zoals ze gaan. Interpersoonlijk gedrag van mensen kan op meerdere manieren worden verkliard of uiteengelegd. Wat valt daarover te leren uit de psycho-analyse of van Jung of vanuit een transactionele analyse?

Kritische theorieen die zulke achterliggende vragen onderzoeken als: Wat voor veronderstellingen maken we bij het analyseren van gebeurtenissen? Welke aspecten laten we zitten? Welke wardeoordelen bepalen onze positie?

Deze laatste soort wan theorieën ondervraagt voortdurend de claims, veronderstellingen, tegenstellingen, omissies en waurdeoordelen die kleven aan de verschillende normatieve, beschrijvende en interpretatieve invalshoeken (Burgoyne \& Reynolds, 1997, 3-4).

Vooral de laatste kritisch (theoretische) benadering is erg stimulerend om de wat lastigere vragstukken en thema's op het terrein van management educatie te adresseren en niet links te laten liggen. Een 
paar voorbeelden van moeizame, maar relevante thema"s laten dat zien: - Dragen principes als openheid, eerlifkheid en vertrouwen, die vaak gepropageerd en/of verondersteld worden bij management onderwijs en -trainingen metterdaad bij aan efficiency en satisfactie of vragen ze van de managers vooral nog meer discipline en controle?

- Als managers worden aangespoord om naar zichzelf te kijken en naar de eigen leerstijl, of naar zichzelf als teamlid of als persoonlijkheidstype helpen we ze dan om zichzelf beter te leren kennen of ontmoedigen we juist dat, onbedoeld ze zich - waar dat nodig is - willen en kunnen aanpassen, en dus zelf uitmaken waarwoor ze willen gaan?

- Zijn zulke populaire en dus ook bij management educatie veel woorkomende concepten als: missie, visie, empowerment en zelf sturende teams, echt zo bevrijdend en efficiency-bevorderend als ervan gezegd wordt? Staan ze voor wat metterdaad gebeurt of vergulden ze vooral de (bittere) pil wan afslanken en inkrimpen?

- Hoe staat het met de neiging om bij management onderwijs en trainingen het accent wooral te leggen op een technische en instrumentele aanpak wan problemen, zonder veel aandacht te schenken aan morele en ethische keuzen die wak net zo goed voorliggen?

Er zijn genoeg redenen om deze kritische benadering blijvend stevig in management educatile te verankerem, zeker nu managers toenemend in aanraking komen met zulke complexe vraagstukken als discriminatie. minderheden, milieuvervuiling en ethiek. Wil men met dit soort van kwesties goed omgaan, dan kan men zich niet meer ver aten op vooraf gegeven vaste formules of een technische aanpak. Daarmee wil niet zijn gezegd dat academici hierover per definitie bevrijdender kunnen spreken, integendeel. Juist in de praktijk blijkt wat well en niet kan en/of dat nog verantwoord is. Maar de kritische reflectie daarop, inclusief op de achterliggende opvattingen, wordt - voor beide belanghebbende partijen - begunstigd bij een geregeide interactie tussen academie en bedrijfsleven. 


\section{Hebzucht: meer leiders willen steeds meer en meer ...!}

De afgelopen jaren is gebleken dat nogal wat bedrijwen zijn geleid door mensen die net zo min een leider waren als de Tovenaar van Oz dat was. Het waren huichelaars, die zich woordeden en praatten als leiders, maar zich gedroegen als piraten. Ze konden hun gebrek aan echt leider-

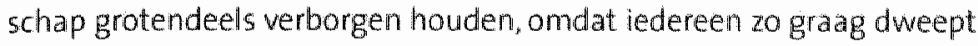
met beroemdheden en leiders, en van de leiders van grote bedrijven beroemdheden maakt. Ze werden gevleid door de media, met weel kwispelstaartende jourmalisten, die voedsel gaven aan de mythe dat zij het geheim kenden, niet alleen van hoe je geld maakt, maar ook alles afwisten van het mysterie van leiderschap. De 'keizerlike' status van deze topbedriffsleiders was terug te vinden in hun enorm geëxplodeer de salarissen. Alleen al de amerika anse CEO's verdienden in zaoo meer dan $300 x$ het salaris wan een gewone arbeider, 30 jaar eerder was dat nog 'slechts' $44 x$.

Vanaf deze eeuw donderde de ene na de andere topman van zijn voetstuk: fraude, voorkennis, bedrog en andere bedrijfsmisdaden. 20 brandden de topmensen af wan Enron, Adelphia, Worldcom, Global Crossing, Arthur Andersen, Imclone, de FBI, Tyco, maar ook in Europa: de EU. Ahold, Parmalat en Mannesmann om de meest opvallende te noe. men

Hoe kon de geloofwaardigheid van topmensen zo snel, zo diep en zo hard onderuit gaan? De belangrijkste oorzaken zijn hebzucht, oneerlijkheid en functie misbruik door verschillende mensen aan de top. Maar misschien wel de belangrijkste reden waarom het bedrijfsleiderschap zo kwetsbaar werd was het overall falen om een cultuur van oprechtheid en openhartigheid te scheppen.

Het is niet makkelijk on kritiek te verwelkomen, hoe eerlijk en tactvol ook gebracht. Maar de bereidheid daar wel voor open te staan is een van de onvervangbare kwaliteiten van echte leiders. Klassiek woorbeeld is Samuel Goldwyn, de grote baas van Hollywood, die na een aantal flops al zijn jaknikkers bijeen had geroepen en hen toesnauwde: " $k$ wil dat jullie mij vertellen wat fout is met MGM, ook al houdt dat in dat je eruit wiegt!" Een variant hierop is de cartoon, die latat zien dat ledereen die tegen is moet zeggen "ik wertrek". 
Het is natuurijlk niet genoeg alseen directeur zegt dat ie steeds de waarheid wil horen. De medewerkers moeten kunnen rekenen op een zekere immuniteit, de belofte dat ze misschien niet beloond worden als ze zeggen hoe de zaken er echt voor staan, maar er zeker niet op zullen worden aangekeken. Weinige leiders kunnen of wilten zoin belofte doen. De meesten gaan in plats daarvan voor een soort van compromiscultuur. Hij/zij zegt weliswaar eerlijke input te willen, maar zegt men een keer waarop 't staat, dan wordt men gemarginaliseerd, zo niet eruit gezet. Dan begrijpen de mensen al snel dat openhartigheid orwelliaans was bedoeld. Men wil niet de warheid horen, maar een soort van halfwaarheid, die de status quo dient. In zo'n atmosfeer willen alleen nog maar erg moedige medewerkers doen wat juist is, ook al betekent dat verzet tegen het systeem het verlies van hun baan én carrière.

Het gekke is dat zulke mensen die aan de bel trekken wooral op afstand worden bewonderd. Zelf, in het echt geconfronteerd worden met een pijnlijke waarheid kunnen de meesten van ons niet uitstaan. Totdat de krantenkoppen verschijnen en de gevolgen onvermijdbaar zijn, vergeten bedrijven en organisaties te vaak dat ze meer zullen lijden door het negeren van die principiële dissidenten dan doar naar ze te luisteren. Dat is riet alleen moreel af te keuren maar ook 'businesswise' ongelooflijk stom!

ledere keer dat een klokkenluider in het nieuws komt, bewijst dat het falen van een leider, die niet doorheeft dat een intern afwijkende opvatting niet een last of " $m$ crisis is, maar wooral een zér goedkope verzekering tegen rampzaligheden (Bennis, 2004, 9-11).

Op de locale sportschool sprak in zijn tijd Socrates graag met mensen die in vorm waren. In worm zijn is alleen mogelijk door goed voor jezelf te zorgen dat wil zeggen zo goed mogelijk je eigen belang na te streven.

Maar Socrates meende juist dat velen niet echt wisten wat goed voor ze was. Hij wees de verleidingstaal van werkeerd leiderschap af, zeker wanneer leiders termen gebruikten als algemeen belang, maatschappelijke verantwoordelijkheid of pollitieke noodzaak. Dat bestempelde hij als rhetoriek, die verborg warom het eigenlijk ging namelijk de eigen macht, status, invloed en geld, veel geld! (Kessels, Boers \& Mostert, 2003 . $156)$ : 


\section{Nawoord}

"Wat blift kont nooit terug"

(Jan Eijkelboom)

Dames en Heren,

Dat elk van u de moeite heeft genomen mij te vereren met uw aanwezigheid en aandacht waardeer ik zeer, hartelijk dank daarvoor! lik hoop dat $u$ zich met mij wilt inzetten voor de Graduate School of International Management, voor die bedrijwigheid in deze brede regio en voor de kennistransfer over en weer.

\section{Geacht College van Bestuur en Faculteitsbestuur}

Dank woor het vertrouwen dat $u$ mij in mei 2002 gaf door mij te benoe. men en die Graduate School of International Management mogelijk te maken. Speciaal dank aan de inmiddels oud-decaan Steven Maijoor en zijn bestuur, die met kracht de motor daar achter waren.

Geachte studenten van de Graduate School

$U$ bent de pioniers en scouts, die ons meehelpen de weg te vinden naar een blijvende bijdrage aan het beter maken van $u$, de bedrijven en orga* nisaties waaraan $u$ bent verbonden ein van onszelf.

\section{Geachte collegamedewerkers}

Zoals $u$ zich, onmiddellijk en met overgave hebt ingezet woor dit nieuwe initiatief is verfrissend en inspirerend. Jullie werkkracht en inventiviteit maakt mijn taak de onze.

Geachte Faculteit en medewerkers ervan

$U$ bent de kurk waarop de nieuwe business school drijft. Uw deskundigheid en de bereidlheid die interactief in te zetten woor onze gezamenlijke executive programma's zal ons allen en onze omgeving te stade komen.

Geachte departementscollega's

$U$ bent een inspirerende context. Ik verheug me op de werdieping van onze samenwerking. 
Dames en Heren uit het bedrifsleven en uit de overheidsbedrijigheid zoals ook bedoeld zal de nieuwe business school zich blijven inspannen steeds te beginnen bij uw uitdagingen. De adequatheid waarmee wij op uw kennis en ontwikkelingsbehoeften reageren, moet steeds uw en daarmee ons belang dienen.

\section{Beste vrienden en kennissen}

Dank voor de goede ontvangst die u mij gaf. $\mid k$ ben blij dat velen van u mij steeds met een glimlach begroeten. Het fijnst is dat $u$ dat meestal doet als ik binnerikom en niet als ik vertrek.

Beste familiegenoten Wij maken deel uit van een familie waar nog genoten wordt, van elkaar en van het leven. We zijn bevoorrecht en ik temeer nu ik er van dichtbij nog meer deelgenoot van ben.

Lieve partners, van toen en nu

Jullie aantrekkelijkheid, charme, kritiek en grootmoedigheid verrijken mij voortdurend. Jullie blijvende steun en vriendschap maken mij een gelukkig mens.

Lieve Bernice Daar staat ie weer in z"n jurk. Gek hè, dat ik vind dat ik wan jou veel leer" Niet perse als jij mij weer eens uitlegt hoe alles eigenlijk is: "Kijk papa. dat zit zo..", maar vooral als ik mijzelf in jouw ogen zie, als ik je naar bed breng. Dan weet ik dat ik moet zijm wat ik zeg.

Ik heb gezegd! 


\section{Geraadpleegde Literatuur:}

M. Alvesson \& H. Willmott (eds), Critical Management Studies, London, 1992.

M. Alwesson \& H. Willmot. Critical Theory and management 5 tudies: An introduction, in : Alvesson \& H. Willmott (ed5), ac, London, 1992

C. Argyris \& D.A. Schön, Organizational Learning : A Theory of Action Perspective. Reading, 1978

C. Argyris \& DA. Schon, Organizational Leaming It, Theory, Methods and Practice, Reading 1996

C. Argyris, Knowtedge for Action; a Guide to overcaming Barriers to Organizational Chonge, San Francisco, 1993

P. van Baalen, Management en Hoger Onderwijs: de geschiedenis wan her academisch management-onderwijs in Nederland, Rotterdam, 1995.

P.J. wan Baalen \& L. Moratis, Management Education in the Network Economy: Its context, content and organization, Dordrecht, 200 .

1. L. Badaracco j. Leading Qutely; an Onorthodox Guide to Daing the Right Things, Cambridge, 2001

W. Baets \& G. van der Linden, The Hybrid Busmess School: Developing knowledge management through management learning, Zeist, 2000.

C. Barnard, The Functions of the Executive, Cambridge, 1938.

1. Baudrillard, On Seduction, in: M. Poster, Selected Writings. Stanford, 988 .

W. Bennis, Valuing a Culture of Candour, in: EBF on Leadership, $2004,9-11$.

H. Bergson. Am Introduction to Methaphysics, London, 193

B. Blanshard Wisdom, in: P. Edwards (ed). The Enguclopedia of Philosophy. New vork, 1967

R.E. Boyatzis, S.S. Cowen \& DA. Kolb, Innowation in Professiond Education Steps on a lourney from Teaching to Learning, San Francisco, 1995

R. ten Bos, Strategisch Denken; op zoek naar neuwe helden, Zaltbommel, 1997 fen 20011 . 
R. Iten Bos, Merkwoardige moraol, Zaltbommel, 1998.

R. Ten Bos, Fashion and Utopia in Management Thinking. Arnsterdam, Philadelphia, 2000.

E. Boyer, Scholarship Reconsidered: Priorities of the Professoriate (Special Report for the Carnegie Foundation for the Advancement of Teaching), Lawrencevitte, 1990

1. Burgoyne \& M. Reynolds (eds.), Management tearning; Integroting Perspectives in Theory and Practice, London. 1997.

f. Burgoynie \& M. Reynolda (eds), The Nature, Use and Acquisition of Managerial Skills and other Attributes in: Personnel Review, 1976.5(4).

G. Burrell, Pandemonium; Towards a Retro-Organization Theory. London, 1997.

M. Calás \& L. Smircich, Voicing Seduction to Silence Leadership, in: M. Calás \& L. Smircich, Postmodern Management Theory, Aldershot. 1997.

5. Caudron. Wake up for New Learning, in: Training and Development, May, 1996.

R. Chia \& 5. Morgan, Educating the Philosopher-Manager: De-signing the Times, in: Management Learming, $27(1) .1996$

R. Chia, Organized Analysis as Deconstructive Practice, Bertin, 1996.

R. Chia "Process Philosophy and Management Learning: Cultivating 'Foresight' in Management, in: I. Burgoyne \& M. Reynolds (eds.) a.c. 1997

CR. Christensen e.a. (eds). Education for Judgment; the Artistry of Discussion Leadership, Boston, 1991.

S. R. Clegg. Strange Fruit hanging from the Knowledge Tree, or Carry on Carping. in: Management Learning, 2003, 375-378.

D.K. Cohen, Teaching Practice Plus ca change.... In: PW. Jackson (ed), Contributing to Educational change, Berkeley. 1989

B. Czamiawska, Writing Management; Organization Theory as a Literary Genre. Oxford. 1999.

B. Cxamiawska, forbidden Knowledge; Organization Theory in Times of Transition, in: Managenent Leaming, 2003.353-365.

A.P. Cregledy, New Directions for Organizational Learning in Eastern Europe, in: Organization Studies, $1996,17(2)$. 
5. Daws \& 1. Botkin. The Monster under the Bed; How Business is Mastering the opportunity of knowledge for profit, New York. 1994 .

P. Drucker, Management, Tasks, Responsibilities, Practices, Oxford, 1974.

R.F. Elmare, Foreword, in: C. Christensen e. a leds), oc. 1991.

1. Elster, Sour Grapes: studies in the subversion of rationality, Cambridge, 1983.

1. Essers \& J. Schreinemakers. The conception of Knowledge and Information in Knowledge Management in : J Schminemakers led. knowledge Management; Organization, Competence and Methodology, Wurzburg, 1996.

L.Farber, Lying, despoir jealousy, enwy, sex, suidde, drugs and the good lfe, New York, 1976 .

JW. Foppen, B.G.K. Peters \&. M. Stum, Riding the Waves, a Reflective Evaluation on Professionalism, Rotterdarm, 1994.

IWW. Foppen \& B.G.K. Peters Crafting Reflective Professionals, The Challenge of Postgraduate MBA. Education, in: P.J. van Baalen (ed.). New Challenge for Business Schools, Delft, 1995

JW. Foppen, Knowing about Value: Management Learning as Knowledge Management, Delft. 1998.

AW. Foppen, Knowledge Leadership, in: S. Chowdhury, Management 21C, london, 2000.

S. Fox, Debating Management Learning, in: Management Learning, 1994, 25(1).

S. Fox, Debating management learning 11, in: Management Learning, 1994, 25 (A)

5. Fox From Management Education and Development to the Study of Mamagement Learning in: 1. Burgoyne \& M. Reynolds (eds). 0.6., 1997.

O. Tranks \& R. Rawlinson, The Theory of Leadership and the Leadership of Theory, in: EBF on Leadership. $2004,3-5$.

P. Freire \& 1, 5hor, A Pedagogy for Liberation. Dialogues on Transforming Education. london, 1987

P. Freire. The Pedagogy of the Oppressed. New York 1990

R. French \&. C. Grey (eds.), Rethinking Management Education, London, 1996. 
K de Galan, Tramen, een prakthkgids, Hathem, 2003.

R. Gibson, Critical Theory and Education, London, 1986.

A, Giddens, Beyond Left and Right: The Fulure of Radical Poltics. Cambirige. 1994.

H.L. Goodall ir. Casing a Promised Land, Carbondale rg94.

R. Coodwin, How the Leopard Changed its Spots, New York, 1994.

R. Greene, The Ait of Seduction. Landon, $200 \%$.

C. Giret, D Knghts \& H. Wilmot, is a Crutical Pedagogy of Management possible? In R. French en C. Orey, oc, 7996

K. Grint, Management: a Sociological introduction, Cambridge, 1995.

K. Crint leadeship; Classical, Contemporary, and Critical Approaches, Oxford, 1997.

K. Grint, Fuzzy Management: Contemporay laeas and Practices at Work, Oxford. 1997.

D. Hague "The firm as a universty in: Demos, 8,1996 .

A. Huczynski, Management Gunis: What makes them and how to become one, London, 1993 .

D. Isenberg, Some Hows and Whats of Managerial Thinking: Implications for Future Army Leaders, In: Leadership on the Future Battlefield, New York, 1985.

1. Kessels, E. Boers \& P. Mostert, Vrije Rumte: Flosoferen in Organisaties. Amsterdarn, 2009 .

MS. Knowles, The Adult Learner; A Negrected Species, Hourton, 1990.

1.P. Kolter \& L. Wesket, Conparate Culture and Peromance, New Work, 1992

B. Latour. We have never been modern. New York. 1993.

B. L.t tour, Aramis or the Love of Technology, Cambridge. 1996.

R.R. Locke. Maragement and Higher ducation since ng9o; the infuchce of America and Japan on West-Germany Great Brttain and France, Cambridge, 1989.

R.R. Locke, The collapse of the American Management Mystique, Oxford, 1996. 
J.F Lyotard, La condition postmodeme, Rapport sur de savoir Paris, 1979.

J.F. Lyotard. Lenthousiasme la critgue kontienne de thistoire, Paris, 1986.

MACIS Project, Development of a Manogement Curriculum for the Infombtion Society Athens, 1999 .

1. Mangham \& A. Pye, The Doing of Maragement, Oxford, 1991.

1. Micklethwait \& A. Woalridge, The Witch Dactors: Making sense of the Management Gurus, New York, 1996.

H. Mintzberg. The Nature of Manggerial Work, Englewood Clifis, 1980

5. Nkomo. Teaching as an act of Scholarship. Bn: Prost 8 M.laylor. Rhythms of Academic Lfe; Personal Accounts of Careers in Academia, London "1996.

H.R. Pagels, The Dreams of Reason, New York, 1988.

R.S. Peters, Ethics and Education, London, 1970.

L. Porter \& L. McKibbin, Managenent education and development: drift or thrust into the 21st century? New York, 1988.

N. Raab, Becoming an expert in not knowing, in: Management Learning. 28(2), 1997

1. Ridderstrale \& K. Nordstrom, Funky Business; Talevt makes capital dance, Stockhoim, 1999.

J. Ridderstrale \& K. Nordstrom, Karaoke Capitalism, Management for Mankind. Stockholm, 2003.

1. Roberts, Managenent Education and the Limits of Technical Rationality: The Conditions and Consequences of Management Practise, in $R$ French \& C. Grey (eds), 0.t, 1996

R. Rorty, Truth and Progress; Philosophical Papers H. Cambridge. 1998.

D. Rushkoff: Playing the Futwre; How Rids Culture canteach ws to thrive in an Age of Chaos, New tork, 1996.

E. Schein, Organizational Cwture and Leadership, San Francisco, 1985.

DA Schon, The reflective Practitioner, New Vork, 1983 . 
DA Schor Educoting the Reflective Practitioner Toward a new Design for keaching and Learning in the professions San Fancisco, 1987.

B. Sievers, Work, Death ond Life Itself; Essays on Manggemen and Organization. Berlin, 1994 .

R. C.K. Siu, The Man of many Qualties, a Legay of the / Ching. Cambridge, 1968 .

R. Smulyan. Whot is the Nome of this Book? Englewood Cliffis, 1978 .

IG. Sperling \& RW. Tucker, Adult-centered Universities; Educathon's Least Cost Way to a World Class Work Force, in Adut Assessment Forum, 1993 (spring)

K.M. Sutclffe, What Executives notice: Accurate perceptions in top management leams, in: Academy of Manogement Joumal. 37. 1994, 1360-1378.

D. Tapscott, Growing up Digital: the Rise of the Ner Generation, New York "1997.

1. Tolstoy. War and Peace, Oxford, 1991.

Torino Group, Re-designing managing development in the new Europe, ETF, 1998.

A.A. Vicere \& R.M. Fumer, Leadephip by Design; How Benchnark companies sustain success through investment in continuous leaning. Boston, 1998.

R, Vince, Experiential Management Education as the Practice of Change, in: $R$. French en C. Grey (eds.), o. C. 1996.

R. Vince, Managing Change: Reflections on Equality and management Leaning. Bristol: 9996.

S.R. Watson, The Place for Universities in Managenant Education in: Jourmal of general Management, $1993.19(2)$.

K. Weick, Sensemaking in Orgarization, Thousand Oaks, 1995

K. Weick, The Attude of Wiscom. Ambivalence as the Optimal Compromise, in: $K$. Waick, Making Sense of the Organization, Oxford, 2001, 361-379.

K. Weick, Making Sense of the Organdzation, Oxford, 2007 .

K. Weick, Commentary on Camniawska, in: Management Leaming. $2003,379-382$.

A.N. Whitehead, Process and Reality. New Vork, 1929.

A.N. Whitehead, Adventures of ldeas, Harmondsworth, n933. 
A.N. Whitehead, The Airms of Education, Wew York, 1949.

H. Willmott, Critical management Laming, in: I Burgoyne \& M. Reynolds (eds.). o.

1. Wittgenstein, Tractotus Logico-Philosphicus, London. 1992 .

B. Zander \& R.S. Zander, The Art of Possibitity Transforming Professiond and Personal Lfe, Cambindge, 2000. 